\title{
Hormone therapy and breast cancer: emerging steroid receptor mechanisms
}

\author{
Meghan S Perkins, Renate Louw-du Toit and Donita Africander \\ Department of Biochemistry, Stellenbosch University, Matieland, South Africa \\ Correspondence should be addressed to D Africander: drho@sun.ac.za
}

\begin{abstract}
Although hormone therapy is widely used by millions of women to relieve symptoms of menopause, it has been associated with several side effects such as coronary heart disease, stroke and increased invasive breast cancer risk. These side effects have caused many women to seek alternatives to conventional hormone therapy, including the controversial custom-compounded bioidentical hormone therapy suggested to not increase breast cancer risk. Historically, estrogens and the estrogen receptor were considered the principal factors promoting breast cancer development and progression; however, a role for other members of the steroid receptor family in breast cancer pathogenesis is now evident, with emerging studies revealing an interplay between some steroid receptors. In this review, we discuss examples of hormone therapy used for the relief of menopausal symptoms, highlighting the distinction between conventional hormone therapy and custom-compounded bioidentical hormone therapy. Moreover, we highlight the fact that not all hormones have been evaluated for an association with increased breast cancer risk. We also summarize the current knowledge regarding the role of steroid receptors in mediating the carcinogenic effects of hormones used in menopausal hormone therapy, with special emphasis on the influence of the interplay or crosstalk between steroid receptors. Unraveling the intertwined nature of steroid hormone receptor signaling pathways in breast cancer biology is of utmost importance, considering that breast cancer is the most prevalent cancer among women worldwide. Moreover, understanding these mechanisms may reveal novel prevention or treatment options and lead to the development of new hormone therapies that do not cause increased breast cancer risk.
\end{abstract}

\author{
Key Words \\ - breast cancer \\ - custom-compounded \\ bioidentical hormones \\ - estrogens \\ - menopausal hormone \\ therapy \\ - progestins \\ - steroid receptor crosstalk
}

Journal of Molecular Endocrinology (2019) 61, R133-R160

\section{Introduction}

Menopause is characterized by the natural, age-related decrease in endogenous estrogen production in women, often leading to a variety of symptoms such as hot flashes, mood swings and night sweats (Johnson 1998, Greendale et al. 1999, Marsden 2003). Conventional United States Food and Drug Administration (FDA)-approved hormone therapy (HT) has been used for decades to alleviate these symptoms and is typically administered as estrogen alone to hysterectomized women or an estrogen-progestin combination to women with a uterus (Johnson 1998, Greendale et al. 1999, Marsden 2003, Cuzick 2008). While the estrogen component alleviates the symptoms of menopause by compensating for reduced endogenous estrogen production, the progestin constituent 
counteracts the proliferative effects of estrogens on the uterine epithelium (Johnson 1998). Despite the fact that HT is effective in relieving menopausal symptoms, some HT regimens have been associated with several severe side effects including coronary heart disease, stroke and increased invasive breast cancer risk (Writing Group for the Women's Health Initiative Investigators 2002, Million Women Study Collaborators 2003, Krieger et al. 2005, Vickers et al. 2007, Cuzick 2008, Marjoribanks et al. 2017). Considering that breast cancer is the most prevalent cancer among women in developed counties (Ferlay et al. 2015, Torre et al. 2015, Siegel et al. 2016), the association between HT and increased breast cancer risk is of significant concern.

The increased breast cancer risk linked to conventional HT has caused many women and medical professionals to seek various safer HT options, including the use of 'natural' alternatives such as custom-compounded bioidentical HT (bHT) (Curcio et al. 2006, Gass et al. 2015). Notably, some bioidentical hormones such as bioidentical estradiol $\left(\mathrm{bE}_{2}\right)$ or bioidentical progesterone $\left(\mathrm{bP}_{4}\right)$ are available in FDAapproved standard-dose prescription medications (Sood et al. 2011, 2014). However, unlike these FDA-approved HT products containing bioidentical hormones, customcompounded bHT formulations are administered in personalized doses and are typically composed of a mixture of up to six hormones (Pinkerton 2012, 2014). Uncertainty remains regarding the efficacy and safety of custom-compounded bHT, especially pertaining to these multiple-hormone combination therapies (Pinkerton 2012, 2014). Although proponents of bHT claim that there is in fact evidence to support the efficacy and safety of custom-compounded bHT in terms of breast cancer risk (Boothby et al. 2004, Bosarge \& Freeman 2009), these claims are unsubstantiated due to the lack of large-scale, double-blinded clinical trials investigating custom-compounded multiple-hormone bHT regimens at various doses.

Estrogen only and estrogen-progestin combination conventional HT have both been implicated in increased breast cancer risk; however, evidence suggests that estrogen-progestin combination therapies are associated with a greater increased risk than estrogen-alone therapies (Writing Group for the Women's Health Initiative Investigators 2002, Million Women Study Collaborators 2003, Fournier et al. 2005, 2008a, Marjoribanks et al. 2017). Estrogens predominantly mediate their effects by binding to the estrogen receptor (ER), while progestins are synthetic progestogens (progesterone receptor (PR) ligands) that were designed to mimic the activity of the natural progestogen, progesterone $\left(\mathrm{P}_{4}\right)$, by binding to the PR. However, it is known that some progestins can bind to the glucocorticoid receptor (GR), mineralocorticoid receptor (MR), androgen receptor (AR) (Koubovec et al. 2005, Africander et al. 2013, 2014, Louw-du Toit et al. 2017, reviewed in Schindler et al. 2003, Africander et al. 2011, Hapgood et al. 2014) and/or the ER (Larrea et al. 2001, Escande et al. 2006, Louw-du Toit et al. 2017, reviewed in Africander et al. 2011). Whether progestins bind to the ER is contradictory. Some studies suggest that medroxyprogesterone acetate (MPA) and norethisterone (NET) can bind to the ER and elicit estrogenic activity, others suggest that they do not (Larrea et al. 2001, Pasapera et al. 2002, Escande et al. 2006, Lemus et al. 2009, Louw-du Toit et al. 2017). Interestingly, we recently showed that NET-acetate (NET-A), levonorgestrel (LNG) and gestodene (GES) can bind to ER-A, but not ER-B, while $\mathrm{P}_{4}$, MPA, nestorone (NES), nomegestrol acetate (NoMAC) and drospirenone (DRSP) do not bind to either ER subtype (Louw-du Toit et al. 2017). Furthermore, some studies suggest that it is the progestin metabolites rather than the parent progestin itself that bind to the ER. Although a number of studies have investigated effects of progestins via steroid receptors other than the PR (Stanczyk et al. 2013, Hapgood et al. 2014), these studies seldom directly compare different progestins in parallel and often use cell lines that endogenously express many steroid receptors to which progestins can bind, which may result in inaccurate results in terms of binding affinities, as well as potencies and efficacies for gene expression. It is thus essential that the pharmacological properties of the progestins for each individual steroid receptor are determined in parallel in a model system expressing only the receptor of interest, as has been done for MPA and NET via the human GR, MR and AR (Koubovec et al. 2005, Africander et al. 2013, 2014).

The role of the ER, which exists as two subtypes transcribed from two distinct genes (Kuiper et al. 1996, Kuiper \& Gustafsson 1997, Enmark \& Gustafsson 1999), ER-A and ER-B (Ascenzi et al. 2006), has been extensively studied in breast cancer cell biology. Traditionally, estrogens and ER-A were thought to be the main etiological factors contributing to breast cancer pathogenesis, while the PR was considered only as an indicator of a functional ER in breast cancer tumors, implying that the cancer should be sensitive to endocrine-targeting therapies (Horwitz \& McGuire 1975, Carroll et al. 2016, Lim et al. 2016). However, recent studies have highlighted novel roles for the PR in breast cancer cell biology (Daniel et al. 2011, Giulianelli et al. 2012, Mohammed et al. 2015, Singhal et al. 2016). Two main PR isoforms have been 
identified, PR-A and PR-B (Kastner et al. 1990), which have been shown to elicit differential effects (Conneely et al. 2000, 2003, Jacobsen et al. 2002, Richer et al. 2002, Mulac-Jericevic et al. 2003, Faivre \& Lange 2007, Lanari et al. 2012, Brisken 2013). A recent study has shown that unliganded PR-B enhances the effects of ER agonists on ER-A-mediated breast cancer cell proliferation and gene expression by forming a complex with ER-A (Daniel et al. 2015). Moreover, it has been shown that when PR-B is activated by $\mathrm{P}_{4}$ or the synthetic PR agonist, promegestone (R5020), it is recruited to the ER-A complex and redirects the complex to different target genes such that the new gene expression profile is associated with a good clinical outcome (Mohammed et al. 2015). ER-A has also been shown to be required for PR-mediated increased cell proliferation and the expression of PR-regulated genes induced by the progestin MPA (Giulianelli et al. 2012). Interestingly, the presence and critical roles of other steroid receptors in breast cancer cell biology have been highlighted in recent studies. For example, the AR is expressed in $90 \%$ of breast cancer tumors (reviewed in Hickey et al. 2012), and its expression is associated with either a good or poor prognosis depending on the absence or presence of the ER (McNamara et al. 2014). Similarly, GR expression has been associated with a good outcome in ER-A-positive cancers, but is associated with a poor outcome in ER-A-negative cancers (Pan et al. 2011, Leehy et al. 2016).

Steroid receptor signaling pathways have often been studied in isolation; however, it is becoming increasingly clear that these pathways are intertwined. The ability of some steroid hormones, such as progestins, to activate multiple steroid receptors, coupled with the complexity of steroid receptor crosstalk, highlights the intricacies of the mechanisms through which hormones used in HT may increase breast cancer risk and promote breast cancer pathogenesis. In order to elucidate the involvement of steroid receptor crosstalk in the mechanism behind HT and increased breast cancer risk, additional comparative studies of hormones used in HT are need at the cellular level. The aim of this review is to highlight differences between conventional HT and custom-compounded bHT and to discuss known mechanisms behind conventional HT-induced increased breast cancer risk with an emphasis on the role of steroid receptor crosstalk.

\section{Menopause and hormone therapy}

Menopausal transition typically occurs in women between the ages of 40 and 60 years and is characterized by the natural age-related loss of ovarian follicular function leading to decreasing endogenous estrogen, $\mathrm{P}_{4}$ and testosterone levels (Table 1) (Johnson 1998, Greendale et al. 1999). There are three main endogenous human estrogens, namely $\mathrm{E}_{2}$, estriol $\left(\mathrm{E}_{3}\right)$ and estrone $\left(\mathrm{E}_{1}\right)$, the latter being the most abundant circulating estrogen in postmenopausal women (Table 1). However, $\mathrm{E}_{1}$ is not present in sufficient levels to prevent symptoms of menopause, such as amenorrhea, hot flushes, night sweats, vaginal atrophy and mood fluctuations (Johnson 1998, Greendale et al. 1999, Bosarge \& Freeman 2009). HT was first administered in the 1930s not only to alleviate these menopausal symptoms (Cuzick 2008), but also to prevent the medical implications of decreased endogenous estrogen levels including osteoporosis, Alzheimer's disease, arthritis, coronary heart disease and cataract formation (Johnson 1998, Greendale et al. 1999). Today, a large variety of HT regimens are commercially available and can be broadly divided into conventional HT and custom-compounded bHT.

\section{Conventional hormone therapy}

The term conventional HT can be interpreted in many ways due to the fast-evolving nature of drug discovery, however, for the purposes of this review, conventional HT will refer to all FDA-approved HT regimens available in the United States of America (USA). Conventional HT regimens are marketed under different brand names and contain either natural, synthetic or bioidentical hormones, which are available in standardized doses and various routes of administration. Depending on the HT, it can be administered orally, subcutaneously, transdermally, intravaginally or by intramuscular injection (Johnson 1998, Marsden 2003).

HT preparations are composed of various hormones that can be ascribed to a specific class. Class A steroids include hormones that are naturally occurring and administered without chemical modification. For example, conjugated equine estrogens (CEEs) containing estrogens such as equilin are extracted from pregnant mare's urine (Bhavnani \& Stanczyk 2012, 2014). Although these steroids are naturally occurring, they are not endogenous to the human body (Bhavnani \& Stanczyk 2012, 2014). Class B steroids are often referred to as natural or bioidentical; however, these hormones are chemically synthesized from a natural steroidal precursor using numerous chemical reactions (Hudson 1996) and are thus semi-synthetic (Taylor 2005, Cirigliano 2007, Chervenak 2009, Bhavnani \& Stanczyk 2012). 
Table 1 Serum estradiol $\left(E_{2}\right)$, estriol $\left(E_{3}\right)$, estrone $\left(E_{1}\right)$, progesterone $\left(P_{4}\right)$ and testosterone levels in pre- and post-menopausal women. ${ }^{\mathrm{a}}$

\begin{tabular}{llcc} 
& $\mathbf{E}_{\mathbf{2}}$ & $\mathbf{E}_{\mathbf{3}}$ \\
${$\cline { 1 - 1 }$(\mathrm{pg} / \mathrm{mL})} }$ & & $7-400$ & $8-2408$ \\
Postmenopausal $(\mathrm{pg} / \mathrm{mL})$ & $1-20$ & & $<10$ \\
\hline
\end{tabular}

\begin{tabular}{c}
\hline $\mathbf{E}_{\mathbf{1}}$ \\
\hline $12-144$ \\
$7-44$ \\
\hline
\end{tabular}

\begin{tabular}{c}
\hline $\mathbf{P}_{4}$ \\
\hline $566-15,700$ \\
$39-700$ \\
\hline
\end{tabular}

\begin{tabular}{c}
\hline Testosterone \\
\hline $217-2200$ \\
$461-1050$ \\
\hline
\end{tabular}

aMayo Medical Laboratories, Dunn et al. (1981), Cummings et al. (1998), Markopoulos et al. (1988), Pujol et al. (1998), Burry et al. (1999), Wright et al. (1999), Elmlinger et al. (2002), Lewis et al. (2002), Chatterton et al. (2003), Labrie et al. (2003), Wren et al. (2003), McTiernan et al. (2004), Vashisht et al. (2005), Cirigliano (2007), Rothman et al. (2011), Falk et al. (2012), Du et al. (2013), Depypere et al. (2015).

Class C steroids differ from class B steroids in that they are synthesized from non-steroidal, rather than steroidal, precursors in a process called total synthesis (Bhavnani \& Stanczyk 2012). The shortcoming of class B and C steroids is that various isomers are produced during the synthesis process, with only one of these isomers structurally identical to the endogenous human hormone (Bhavnani \& Stanczyk 2012, Gass et al. 2015). For example, during total $\mathrm{E}_{1}$ synthesis, eight racemates (differentiated by the left- and right-handed enantiomers of a chiral molecule) are produced, resulting in 16 isomers of which only one is structurally and biochemically identical to endogenous human $\mathrm{E}_{1}$ (Bhavnani \& Stanczyk 2012). The remaining isomers have different structures and varying degrees of estrogenicity, while some are even completely inactive (Bhavnani \& Stanczyk 2012). Lastly, class D steroids are manmade steroidal compounds synthesized either from the same steroidal plant precursors as class B hormones by semi-synthesis or from non-steroidal starting material by total synthesis (Bhavnani \& Stanczyk 2012). Examples of class D steroids include estrogens such as estropipate, esterified estrogens and ethinylestradiol (EE), as well as progestins such as MPA, NET-A, LNG and norgestimate (NGM).

Premarin is an example of a HT containing natural CEEs and has been effective in relieving menopausal symptoms from as early as 1942 (Cuzick 2008). Various other estrogens have subsequently become available for use in conventional HT and include synthetic, rather than natural CEEs, $\mathrm{bE}_{2}$, as well as the less commonly used esterified estrogens, estropipate and synthetic $\mathrm{E}_{2}$ derivatives including $\mathrm{EE}, \mathrm{E}_{2}$ valerate, $\mathrm{E}_{2}$ cypionate and $\mathrm{E}_{2}$ acetate (Table 2). Although estrogen-only HT effectively relieves menopausal symptoms, studies in the 1960s reported increased incidence of endometrial cancer in Premarin users (Smith et al. 1975, Weiss et al. 1976, Cuzick 2008). This necessitated the addition of a progestin to CEE regimens for women with a uterus, to prevent estrogen-induced endometrial hyperplasia (Cuzick 2008). Progestins are used to mimic the activity of $\mathrm{P}_{4}$, as they have a longer half-life and a higher bioavailability (Bhavnani
\& Stanczyk 2012, Stanczyk et al. 2013). Products such as Provera (MPA only) and Prempro (CEE-MPA) (Table 3) thus became commercially available as early as 1965 (Nachtigall et al. 1979). Although Provera is produced as a progestin-only HT, it is administered in combination with an estrogen-only HT (Stefanick 2005). Various generations of progestins have subsequently been developed, derived from $\mathrm{P}_{4}$, T or the MR antagonist spironolactone, where each new generation is designed to have a greater affinity for the PR and elicit biological effects more similar to $\mathrm{P}_{4}$ than progestins from the earlier generations (Sitruk-Ware 2004, Sitruk-Ware \& Nath 2010, Africander et al. 2011). Note that $\mathrm{P}_{4}$ derivatives can be either 17-hydroxy- $\mathrm{P}_{4}$ derivatives or 19-Nor- $\mathrm{P}_{4}$ derivatives (Fig. 1).

Progestins currently used in FDA-approved HT include the first-generation progestins MPA and NET-A, secondgeneration progestin LNG, third-generation progestin NGM and the fourth-generation progestin, DRSP (Fig. 1). Interestingly, not all progestins are used clinically in the USA. For example, although NoMAC is used in HT in Europe (Fournier et al. 2005), it is not used in the USA. However, NoMAC and other progestins such as NES and GES (Fig. 1) are currently being investigated in clinical trials for use in contraception in the USA (Sitruk-Ware \& Nath 2010, Bahamondes \& Bahamondes 2014). The continual evolution of HT is thought to be aimed at designing estrogens and progestogens that effectively manage menopausal symptoms without eliciting unwanted side effects. More recent advances in HT evolution saw the introduction of bioidentical hormones. FDA-approved bE $_{2}$-only products (Files et al. 2011, The North American Menopause Society (NAMS) 2012 Hormone Therapy Position Statement Advisory Panel 2012) are available in standardized doses in products such as Alora, VivelleDot, Divigel, Elestrin, Estrogel and Estrace (Table 2), or in combination with progestins such as NET-A (Activella, Mimvey, Combipatch), DRSP (Angeliq), NGM (Prefest) or LNG (Climara Pro) (Table 3). Interestingly, although FDA-approved $\mathrm{bP}_{4}$ is available as Prometrium in the form of a cream or as a pill that is administered together with an estrogen-only HT, there are no standardized 
Table 2 FDA-approved estrogen-only HT products.a

\begin{tabular}{|c|c|c|c|c|c|}
\hline Composition & Products & $\begin{array}{l}\text { Route of } \\
\text { administration }\end{array}$ & $\begin{array}{c}\text { Administered doses } \\
(\min -\max )(\mathrm{mg})\end{array}$ & $\begin{array}{c}\text { Serum } \mathbf{E}_{\mathbf{2}} \\
(\mathrm{pg} / \mathrm{mL})\end{array}$ & $\begin{array}{c}\text { Serum } \mathbf{E}_{\mathbf{1}} \\
(\mathrm{pg} / \mathrm{mL})\end{array}$ \\
\hline \multirow[t]{2}{*}{ Natural CEE } & Premarin & Pill & $0.3-1.25$ & NA & $87-4500$ \\
\hline & & Vaginal cream & $0.625 *$ & NA & $42-600$ \\
\hline Synthetic CEE & Cenestin, Enjuvia & Pill & $0.3-1.25$ & NA & $20-85$ \\
\hline \multirow[t]{8}{*}{$\mathrm{bE}_{2}$} & $\begin{array}{l}\text { Alora, Climara, Esclim, } \\
\text { Estraderm, Estradot, } \\
\text { Menostar, Minivelle, } \\
\text { Vivelle-Dot }\end{array}$ & Patch & $0.025-0.1$ & $6-174$ & $9-65$ \\
\hline & Divigel, Elestrin, Estrogel & Topical gel & $0.025-2.0 *$ & $9-67$ & $33-66$ \\
\hline & Estrace, Gynodiol & Pill & $0.5-2.0$ & $203-355$ & ND \\
\hline & Estrace & Vaginal cream & $0.1 *$ & ND & ND \\
\hline & Estrasorb & Topical cream & $2.5 *$ & $59-70$ & ND \\
\hline & Estring & Vaginal insert & 2.0 & $8-63$ & $44-66$ \\
\hline & Evamist & Topical spray & $1.53^{\#}$ & $11-57$ & NA \\
\hline & Vagifem & Vaginal tablet & $0.01-0.025$ & $6-21$ & $17-28$ \\
\hline \multicolumn{6}{|l|}{$\mathrm{E}_{2}$ derivatives } \\
\hline $\mathrm{E}_{2}$ valerate & Delestrogen & IM injection & $10-40$ & ND & ND \\
\hline $\mathrm{E}_{2}$ cypionate & Depo-Estradiol & IM injection & $1.0-5.0$ & ND & ND \\
\hline \multirow[t]{2}{*}{$\mathrm{E}_{2}$ acetate } & Femring & Vaginal ring & $0.05-0.10$ & $41-76$ & $36-46$ \\
\hline & Femtrace & Pill & $0.45-1.8$ & $57-177$ & $155-680$ \\
\hline \multirow{2}{*}{$\begin{array}{l}\text { Esterified } \\
\text { estrogen }\end{array}$} & Menest & Pill & $0.3-2.5$ & ND & ND \\
\hline & Estragyn & Vaginal cream & $1.0 *$ & ND & ND \\
\hline \multirow[t]{2}{*}{ Estropipate } & Ogen & Pill & $0.75-3.0$ & ND & ND \\
\hline & & Vaginal cream & $1.5^{*}$ & ND & ND \\
\hline
\end{tabular}

*mg hormone per g cream; \#mg hormone per single HT spray; aBowen et al. (1998); Premarin tablets package insert, Wyeth Pharmaceuticals Inc.; Premarin vaginal cream package insert, Wyeth Pharmaceuticals Inc.; Cenestin package insert, Teva Pharmaceuticals USA, Inc.; Enjuvia package insert, Barr Pharmaceuticals, Inc.; Alora package insert, Watson Pharmaceuticals, Inc.; Climara package insert, Bayer HealthCare Pharmaceuticals Inc.; Esclim package insert, Serono Laboratories, Inc.; Estraderm, Novartis Pharmaceuticals Corporation; Estradot package insert, Novartis Pharmaceuticals Australia Pty Ltd; Menostar package insert, Bayer HealthCare Pharmaceuticals Inc.; Minivelle package insert, Novartis Pharmaceuticals Corporation; Vivelle-dot package insert, Novartis Pharmaceuticals Corporation; Divigel package insert, Upsher-Smith Laboratories Inc.; Elestrin package insert, Bradley Pharmaceuticals Inc.; Estrogel package insert, ASCEND Therapeutics Inc.; Estrace tablets package insert, Warner Chilcott Inc.; Gynodiol package insert, Barr Pharmaceuticals Inc.; Estrace vaginal cream package insert, Allergan USA, Inc.; Estrasorb package insert, Novavax, Inc.; Estring package insert, Pfizer Inc.; Evamist package insert, Ther-Rx Corporation; Vagifem package insert, Novo Nordisk Inc.; Delestrogen package insert, Monarch Pharmaceuticals Inc.; Depo-Estradiol package insert, Pfizer Inc.; Femring package insert, Warner Chilcott Inc.; Femtrace package insert, Warner Chilcott Inc.; Menest package insert, Monarch Pharmaceuticals Inc.; Estragyn package insert, Searchlight Pharma Inc.; Ogen tablet package insert, Pfizer Inc.; Ogen vaginal cream package insert, Pfizer Inc.).

$\mathrm{bE}_{2}$, bioidentical estradiol; $\mathrm{CEE}$, conjugated equine estrogens; $\mathrm{E}_{1}$, estrone; $\mathrm{E}_{2}$, estradiol; IM, intramuscular injection; NA, not applicable as these HT products do not contain the relevant hormone; ND, serum concentrations have not been reported.

FDA-approved $\mathrm{bE}_{2}-\mathrm{bP}_{4} \quad$ combination formulations available. Notably, $\mathrm{bP}_{4}$ is administered in a micronized form, referring to the fact that the particle size has been decreased to generate finer powders that are more readily absorbed, and thus, have an increased bioavailability to compensate for the short half-life of the natural hormone (Chaumeil 1998, Boothby et al. 2004). However, both oral and transdermal micronized $\mathrm{bP}_{4}$ formulations are dissolved in peanut oil and consequently cannot be used by women with nut allergies (Sood et al. 2013, Xie et al. 2014, Mirkin et al. 2015, Stuenkel et al. 2015, Santoro et al. 2016). Another alternative HT regimen involves the use of selective estrogen receptor modulators (SERMs). SERMs elicit tissue-selective estrogenic activity by acting as ER agonists in bone tissue, increasing bone mineral density and bone strength, but as ER antagonists in the breast and endometrium to prevent breast and endometrial cancer (Komm \& Chines 2012). FDA approval was recently granted to Duavee, a CEE-SERM (bazedoxifene) combination to be used for the relief of menopausal symptoms as well as to prevent postmenopausal osteoporosis (Kharode et al. 2008, Pinkerton et al. 2009, Bachmann et al. 2010, Kagan et al. 2010, Komm \& Chines 2012).

Estrogen only and progestogen-containing FDAapproved HT products are outlined in Tables 2 and 3 , respectively. These tables indicate the routes of administration and dose range of the various HTs and, where available, the resulting serum concentrations of $\mathrm{E}_{2}, \mathrm{E}_{1}, \mathrm{EE}$, the progestogens or bazedoxifene. Although these conventional HT regimens are still widely used and have proved efficient at relieving menopausal symptoms (The North American Menopause Society (NAMS) 

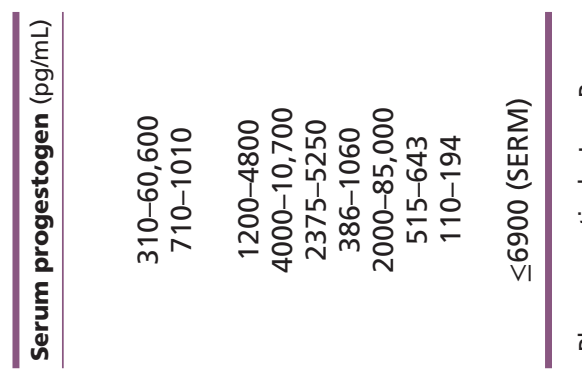

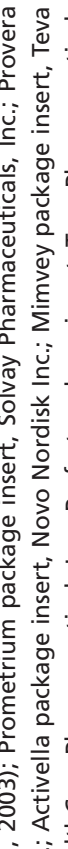

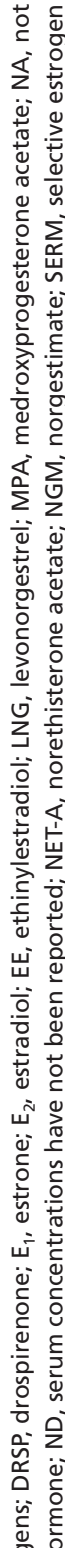

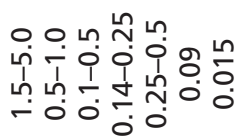

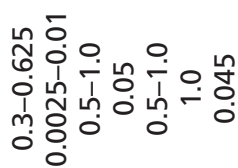

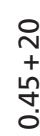

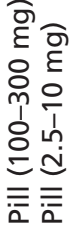

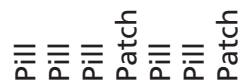

2012 Hormone Therapy Position Statement Advisory Panel 2017), the reported side effects associated with conventional HT have caused so much alarm that many women have sought alternate menopausal relief in the form of custom-compounded bHT (Bhavnani \& Stanczyk 2012).

\section{Custom-compounded bioidentical hormone therapy}

Custom-compounded bHT refers to the personalized bHT regimens containing class B steroids that are prepared by compounding pharmacies and can include any number of bioidentical hormones including bioidentical estrone $\left(\mathrm{bE}_{1}\right)$, estriol $\left(\mathrm{bE}_{3}\right)$, testosterone (bT), dehydroepiandrosterone (bDHEA), $\mathrm{bE}_{2}$ and/or $\mathrm{bP}_{4}$ (Chervenak 2009, Bhavnani \& Stanczyk 2012). Unlike FDA-approved HT, which is available in standardized doses, a customized dose of bHT is prescribed based on a saliva test that estimates serum hormone levels (Boothby et al. 2004, Santoro et al. 2016). However, this method contradicts a global consensus that the lowest possible dose of HT that effectively relieves menopausal symptoms should be prescribed (Bosarge \& Freeman 2009, The North American Menopause Society (NAMS) 2012 Hormone Therapy Position Statement Advisory Panel 2012, de Villiers et al. 2013). Moreover, numerous studies have shown a poor correlation between hormone levels found in saliva and serum, due to saliva hormone levels fluctuating based on time of day, diet and other variables (Boothby et al. 2004, Cirigliano 2007, Fugh-berman \& Bythrow 2007, Bosarge \& Freeman 2009, Chervenak 2009, Santoro et al. 2016).

The safety and efficacy of custom-compounded bHT is controversial and proponents of bioidentical hormones claim that these hormones are natural and identical in structure to endogenous human hormones; hence, they are safer than conventional HT products (Chervenak 2009). This is despite the fact that the proposed 'natural' hormones used in custom-compounded bHT are in fact semi-synthetic and synthesized in a similar manner to the bioidentical hormones used in FDA-approved HT (Cirigliano 2007, Fugh-berman \& Bythrow 2007, Bosarge \& Freeman 2009, Chervenak 2009). However, because of this 'natural' classification, custom-compounding pharmacies may legally dispense products containing bioidentical hormones without obtaining FDA approval for each product (Fugh-berman \& Bythrow 2007, Chervenak 2009). This means that personalized hormone preparations are dispensed without the rigorous quality control checks that FDAapproved drugs are subjected to. Furthermore, unlike 
A

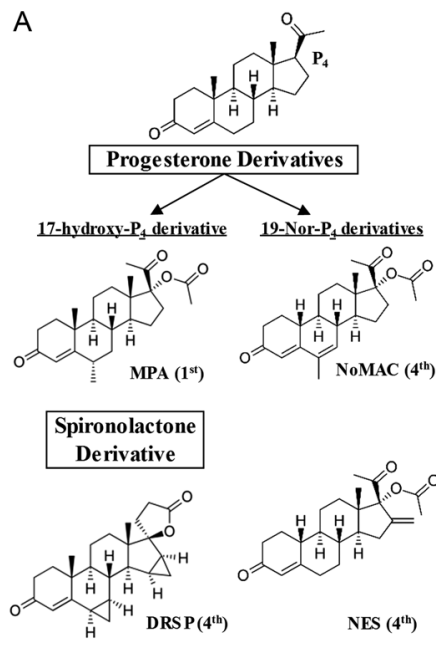

B
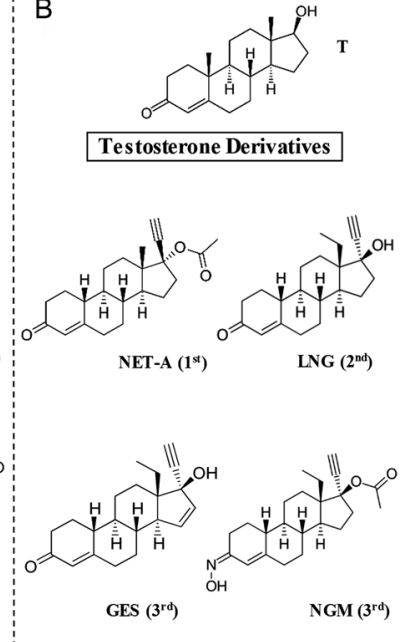

\section{Figure 1}

Structures of various first (1st)-, second (2nd)-, third (3rd)-, and fourth (4th)-generation progestins. Progestins structurally related to (A) progesterone (P4) include the first-generation, 17-hydroxy-P4 derivative, medroxyprogesterone acetate (MPA) and the fourth-generation, 19-Nor-P4 derivatives, nomegestrol acetate (NoMAC) and nestorone (NES), while progestins structurally related to (B) testosterone (T) include the first-generation progestin, norethisterone acetate (NET-A), the second-generation progestin, levonorgestrel (LNG), and the thirdgeneration progestins, gestodene (GES) and norgestimate (NGM). (C) The fourth-generation progestin drospirenone (DRSP) is currently the only progestin structurally related to spironolactone, a MR antagonist. Structures were obtained from Pubchem (https://pubchem.ncbi.nlm.nih. gov).

conventional HT products, custom-compounded bHT products lack black-box warnings of the potential adverse effects of HT (Fugh-berman \& Bythrow 2007, Bhavnani \& Stanczyk 2012, Pinkerton 2014). A major concern raised by randomized FDA checks is the fact that custom-compounded preparations frequently result in accidental under- or overdosing, possibly due to variations in purity and/or human error associated with personalized combination constitution (Cirigliano 2007, Eden et al. 2007, Fugh-berman \& Bythrow 2007, Bhavnani \& Stanczyk 2012, Sood et al. 2013, Pinkerton 2014). Moreover, compounded bHT patches have been shown to yield lower serum estrogen levels than bioequivalent standard-dose $\mathrm{E}_{2}$ patches, emphasizing that the pharmacodynamics of compounded bHT requires further research (Sood et al. 2013).

Clinical trials investigating the safety and efficacy of $\mathrm{bP}_{4}$ creams over a 12-week period have revealed that custom-compounded micronized $\mathrm{bP}_{4}$ creams do not relieve vasomotor symptoms, inhibit the proliferative effects of $\mathrm{E}_{2}$ on the endometrium or improve mood swings and libido (Wren et al. 1999, 2003, Drisko 2000, Wren 2003, Vashisht et al. 2005, Elshafie \& Ewies 2007).
It has been suggested that this may be due to insufficient $\mathrm{bP}_{4}$ absorption and thus low bioavailability (Cooper et al. 1998, Burry et al. 1999, Wren et al. 1999, Carey et al. 2000, O'leary et al. 2000, Lewis et al. 2002). However, the Postmenopausal Estrogen and Progestin Intervention (PEPI) trial revealed that oral micronized $\mathrm{bP}_{4}$ effectively relieves vasomotor symptoms (The Writing Group for the PEPI Trial 1995, Barrett-Connor et al. 1997, Greendale 1998), suggesting that oral micronized $\mathrm{bP}_{4}$ may be more effective at relieving vasomotor symptoms than localized micronized $\mathrm{bP}_{4}$ creams.

Custom-compounded bHT often contains $\mathrm{bE}_{2}$ in combination with $\mathrm{bE}_{3}$ and/or $\mathrm{bE}_{1}$ (Taylor 2005, Bosarge \& Freeman 2009, Chervenak 2009, Pinkerton 2014). Biest or triest combination regimens can be obtained from compounding pharmacies, where a biest is composed of $\mathrm{bE}_{2}$ and $\mathrm{bE}_{3}$ in a 20:80 ratio and a triest is composed of $\mathrm{bE}_{2}, \mathrm{bE}_{3}$ and $\mathrm{bE}_{1}$ in a 10:80:10 ratio (Boothby et al. 2004, Curcio et al. 2006, Fugh-berman \& Bythrow 2007, Sites 2008). Proponents of bHT claim that $\mathrm{bE}_{3}$ and $\mathrm{bE}_{1}$ are weaker, safer estrogens than $\mathrm{bE}_{2}$ (Sites 2008, Chervenak 2009, Holtorf 2009) and that $\mathrm{bE}_{3}$ antagonizes the potent estrogenic activity of $\mathrm{bE}_{2}$ (Melamed et al. 1997, Boothby et al. 2004). However, we have recently shown that both $b_{3}$ and $b_{1}$ are not necessarily weaker estrogens than $\mathrm{bE}_{2}$ in terms of transactivation and transrepression of gene expression, or their effects on breast cancer cell proliferation and anchorage-independent growth (Perkins et al. 2017). Moreover, we showed that $\mathrm{E}_{3}$ did not antagonize $\mathrm{E}_{2}$-induced gene expression, proliferation or anchorage-independent growth of the MCF-7 BUS breast cancer cell line (Perkins et al. 2017). To the best of our knowledge, however, no other detailed comparisons of the agonist and antagonist properties of these hormones for transactivation and transrepression via the ER subtypes have been reported. In fact, the incorporation of $\mathrm{E}_{3}$ into bHT products appears to be based on murine work conducted by Lemon, more than 30 years ago (Lemon 1975 , 1987), showing that $E_{3}$ was more protective against carcinogen-induced neoplasms than $\mathrm{E}_{2}$ or $\mathrm{E}_{1}$ (reviewed in (Taylor 2005)). However, these claims have not been validated in human models (Melamed et al. 1997) and large-scale, double-blinded, placebo-controlled clinical trials evaluating the safety and efficacy of $\mathrm{E}_{3} \mathrm{Or}_{\mathrm{bE}}$ are lacking. However, some preliminary small-scale trials have suggested that $\mathrm{E}_{3}$ sometimes relieves vasomotor symptoms but does not protect against bone loss (Yang et al. 1995, Takahashi et al. 2000), while others have provided evidence that $\mathrm{E}_{3}$ can protect against bone loss (Cheng et al. 1993, Minaguchi et al. 1996, Itoi et al. 1997, 
Kamenov et al. 2000, Hayashi et al. 2002), highlighting the uncertainties regarding $\mathrm{E}_{3}$ use. Interestingly, although there are no $\mathrm{FDA}$-approved $\mathrm{E}_{3}$-containing $\mathrm{HT}$ products (Boothby et al. 2004), $\mathrm{bE}_{3}$ is used in regulated HT products in parts of Europe and Asia (Cirigliano 2007, Lommen \& Mead 2013), where it is, usually referred to as $E_{3}$ rather than $\mathrm{bE}_{3}$ (Wright 2005, Conaway 2011).

Androgens such as bT and bDHEA, are also often used in personalized bHT formulations in combination with estrogens and/or progestogens to relieve the symptoms of menopause (Reed-Kane 2001, Boothby et al. 2004, Eden et al. 2007, Sites 2008). However, observational studies have reported adverse effects of androgen-containing HT such as endometrial cancer, hair loss, acne, hirsutism and deepening of the voice (Greendale et al. 1999, Eden et al. 2007). In fact, cases of endometrial cancer have been reported in users of oral bHT products containing combinations of $\mathrm{bE}_{2}, \mathrm{bP}_{4}$, bT and bDHEA or $\mathrm{bE}_{1}, \mathrm{bE}_{2}, \mathrm{bE}_{3}, \mathrm{bP}_{4}$, bT and bDHEA (Eden et al. 2007). Interestingly, various androgens, including the testosterone precursor and methyltestosterone, are approved for HT use in Europe (Davis 2015), while there is no FDA-approved androgen-containing female HT (Pinkerton 2014, Gass et al. 2015). Moreover, although there is a lack of clinical trials examining the effectiveness and possible side effects of androgen use in HT, bT and bDHEA are distributed by compounding pharmacies in both the USA (Boothby et al. 2004, Cirigliano 2007, Guidozzi et al. 2014) and South Africa (Golding 2009). In terms of breast cancer risk, the inclusion of bT is especially concerning as testosterone can be aromatized to $\mathrm{E}_{2}$ within breast tissue (Hickey et al. 2012) and endogenous testosterone levels are only marginally decreased after menopause (Table 1). This suggests that the incorporation of bT into an estrogen containing bHT may thus result in greater estrogen exposure than intended, which may increase risk of breast cancer development.

Overall, thelackoflarge-scaleclinicaltrialsinvestigating the safety and efficacy of custom-compounded bHT such as biest and triest regimens (Cirigliano 2007, Bosarge \& Freeman 2009), together with the absence of blackbox warnings, lack of thorough regulatory bodies and uncertainties regarding salivary testing, has resulted in a consensus between several organizations including the North American Menopause Society (NAMS), The International Menopause Society (IMS), The Endocrine Society and The European Menopause and Andropause Society (EMAS), recommending against the use of customcompounded bHT (de Villiers et al. 2013).

\section{Hormone therapy and breast cancer risk}

Numerous clinical trials and observational studies have associated conventional HT with multiple side effects such as elevated risk of developing breast, ovarian and endometrial cancers, as well as cardiovascular disease and stroke (Nachtigall et al. 1979, Obel et al. 1993, The Writing Group for the PEPI Trial 1995, Hulley et al. 1998, 2002, Johnson 1998, Greendale et al. 1999, Notelovitz et al. 2002, Waters et al. 2002, Writing Group for the Women's Health Initiative Investigators 2002, Million Women Study Collaborators 2003, Barakat et al. 2006, Veerus et al. 2006, Yaffe et al. 2006, Fournier et al. 2008b, Tierney et al. 2009, Schierbeck et al. 2012, Manson et al. 2013, Sood et al. 2014, Clavel-Chapelon 2015, Hodis et al. 2016, Marjoribanks et al. 2017). Considering that breast cancer is the most common cancer in women worldwide and the leading cause of cancer-related deaths in women in developed countries (Ferlay et al. 2015, Torre et al. 2015), the association between HT and breast cancer risk is alarming. Although several studies reported adverse effects associated with HT prior to 2002 (Nachtigall et al. 1979, Obel et al. 1993, The Writing Group for the PEPI Trial 1995, Hulley et al. 1998), it was the findings of the highly publicized Women's Health Initiative (WHI) (Writing Group for the Women's Health Initiative Investigators 2002) that caused alarm and confusion about the safety of HT. The WHI study was a large-scale randomized, controlled clinical trial that evaluated the benefits and risks of CEE alone in hysterectomized postmenopausal women or CEE in combination with MPA in postmenopausal women with a uterus (Writing Group for the Women's Health Initiative Investigators 2002). The results of the trial suggested that CEE-MPA combinations, but not CEE alone, were associated with increased invasive breast cancer risk (Writing Group for the Women's Health Initiative Investigators 2002). In contrast, the Million Women Study (MWS), a cohort study comprising over one million postmenopausal women from across the United Kingdom, found that the use of estrogen alone or estrogen-progestin combinations were both associated with increased invasive breast cancer risk (Million Women Study Collaborators 2003). Interestingly, this study found increased breast cancer risk with all HT preparations investigated, and no difference in risk between specific estrogens (CEE and EE) or progestins (MPA, NET and LNG) (Million Women Study Collaborators 2003).

Many additional studies investigating breast cancer risk associated with HT use have been conducted (Nachtigall et al. 1979, Obel et al. 1993, Herrington 
et al. 2000, Cherry et al. 2002, Waters et al. 2002, Hulley et al. 2002, Notelovitz et al. 2002, Greenspan et al. 2005, Stefanick et al. 2006, Veerus et al. 2006, Vickers et al. 2007, Fournier et al. 2008a, Tierney et al. 2009, Schierbeck et al. 2012, Clavel-Chapelon 2015, Marjoribanks et al. 2017), often with contradictory results. For example, while the Women's international study of long-duration estrogen after menopause (WISDOM) clinical trial also found increased breast cancer risk associated with CEEMPA use (Vickers et al. 2007), the Heart and Estrogen/ Progestin Replacement Study (HERS) I, HERS II (Hulley et al. 2002) and the Estonian postmenopausal hormone therapy clinical trial (Veerus et al. 2006) among others (Nachtigall et al. 1979, Herrington et al. 2000, Waters et al. 2002, Greenspan et al. 2005), found no increased breast cancer risk associated with CEE or CEE-MPA. It is thus evident that results from the above-mentioned studies are often contradictory and have resulted in much confusion regarding the safety of these HT regimens. However, it is noteworthy that the studies showing no increased breast cancer risk had significantly less participants (Nachtigall et al. 1979, Herrington et al. 2000, Hulley et al. 2002, Waters et al. 2002, Greenspan et al. 2005, Veerus et al. 2006) than the large-scale WHI, MWS and WISDOM studies (Writing Group for the Women's Health Initiative Investigators 2002, Million Women Study Collaborators 2003, Vickers et al. 2007).

Notably, although most clinical and observational studies investigating the association between HT and increased breast cancer risk examined the effects of CEE and MPA, a few studies have in fact investigated other estrogens and progestogens. For example, three clinical trials have reported no increased breast cancer risk associated with the use of oral $\mathrm{E}_{2}$ alone or in combination with NET-A (Obel et al. 1993, Tierney et al. 2009, Schierbeck et al. 2012), the latter of which was previously shown to increase breast cancer risk when used in combination with CEE in the MWS (Million Women Study Collaborators 2003). Similarly, at least one other study reported no increased risk with the use of an $E_{2}$ only patch (Notelovitz et al. 2002), while the Estrogen in the Prevention of Reinfarction Trial found no increased risk with the use of $\mathrm{E}_{2}$ valerate alone (Cherry et al. 2002). However, the Kronos Early Estrogen Prevention Study found increased breast cancer risk associated with the use of $E_{2}$ patches in combination with oral micronized $\mathrm{P}_{4}$, while the Early Versus Late Intervention Trial (ELITE) also found increased risk with oral $\mathrm{E}_{2}$ used in combination with a $\mathrm{P}_{4}$ vaginal gel (reviewed in (Marjoribanks et al. 2017)). In contrast to the above-mentioned studies showing increased breast cancer risk with the inclusion of $\mathrm{P}_{4}$, the PEPI Trial reported no increased breast cancer risk in women administered CEE plus oral micronized $\mathrm{P}_{4}$ or CEE plus MPA (The Writing Group for the PEPI Trial 1995). Similarly, the French E3N cohort study found that estrogen $\left(\mathrm{CEE}\right.$ or $\left.\mathrm{bE}_{2}\right)$ alone or in combination with $\mathrm{P}_{4}$ or dydrogesterone (a progestin not used clinically in the USA) was not associated with increased breast cancer risk. Interestingly, results from the same study showed that other estrogen-progestin combinations containing the progestins MPA, NET-A, medrogestone, chlormadinone acetate (CMA), cyproterone acetate (CPA), R5020 or NoMAC, were associated with increased breast cancer risk (Fournier et al. 2008a, Clavel-Chapelon 2015). This French cohort study also suggested that administration of oral versus transdermal $E_{2}$ does not influence the degree of breast cancer risk (Fournier et al. 2008a, Clavel-Chapelon 2015). Interestingly, a recent Cochrane review examining the adverse side effects of HT compiled the results of 22 clinical studies, including most of the above-mentioned studies, and suggested that estrogen-progestin HT combinations increased breast cancer risk, while use of estrogen-only HT did not (Marjoribanks et al. 2017). It is clear from the above that more clinical and molecular studies investigating the association between different hormones used in HT and breast cancer are needed.

Taken together, the evidence in the literature investigating an association between specific hormones used in HT and increased breast cancer risk is contradictory. However, there are many other hormones used in FDA-approved HT products such as esterified estrogens, $\mathrm{E}_{2}$ acetate, trimegestone and DRSP, or customcompounded bHT products such as $\mathrm{bE}_{3}, \mathrm{bE}_{1}$ and $\mathrm{bT}$, that have not been investigated in large-scale clinical trials or cohort studies, and thus, it is not known whether these steroid hormones are linked to increased breast cancer risk. An added conundrum is whether the increased risk is due to the initiation of new tumors or the promotion of small, pre-existing tumors. Although still a matter for debate, it is most likely due to tumor promotion (Dietel 2010) as women in the WHI and MWS trials developed tumors within the first year of combined HT use, while breast tumors need an average of 7-10 years to grow to a detectable size (Chlebowski et al. 2003). At the molecular level, steroid hormones predominantly elicit their effects by binding to steroid receptors, which are ligandactivated transcription factors belonging to the nuclear receptor superfamily (Griekspoor et al. 2007, Aagaard et al. 2011). 


\section{Steroid receptors as mediators of hormone activity and carcinogenesis}

When steroid hormones enter the bloodstream, they bind to various serum binding proteins such as sex-hormonebinding globulin (SHBG), corticosteroid-binding globulin (CBG) and/or albumin (Table 4). SHBG predominantly binds estrogen and testosterone, while CBG binds cortisol and $\mathrm{P}_{4}$ (Yen et al. 2015). The hormones bound to SHBG or CBG are considered unavailable to tissues, while the free, unbound hormones and those bound to albumin are considered biologically available to enter cells of target tissues and elicit a response by binding to a steroid receptor (Pardridge 1981, Kuhnz et al. 1990, Kuhl 2005). As indicated in Table 4, some estrogens and progestogens bind to SHBG and/or CBG, while others do not, resulting in large differences in the availability of estrogens and progestogens used in HT. For example, while approximately $37 \%$ of serum $\mathrm{E}_{2}$ can bind to SHBG, $16 \%$ of $\mathrm{E}_{1}$ binds, only $1 \%$ of $\mathrm{E}_{3}$ binds and $\mathrm{EE}$ does not bind at all. As a result, $E_{3}, E_{1}$ and $\mathrm{EE}$ are mostly available to enter cells of target tissues (Table 4) suggesting that these estrogens may be more abundant than $\mathrm{E}_{2}$ in target tissues, and therefore, may compete with $\mathrm{E}_{2}$ for binding to the ER. In the same way, progestins also differentially bind to SHBG as shown by $35.5 \%$ of NET and between 47.5 and $73.6 \%$ of LNG binding, while MPA and DRSP do not bind at all (Table 4). Considering that the data in Table 4 indicates that progestogens are mostly available, it is plausible that they may be more abundant in target tissues than endogenous steroid hormones, even when administered at low concentrations, and thus, may compete with these hormones for binding to their cognate steroid receptors.

Steroid hormones can permeate the cell membrane and elicit their effects by binding to steroid receptors, such as the GR and MR, as well as the sex-steroid hormone receptors, the ER, PR and AR (Griekspoor et al. 2007). A high degree of homology exists between the steroid receptor family, and the receptors are organized into four evolutionary-conserved domains (Fig. 2), namely the $\mathrm{N}$-terminal domain containing the ligand-independent activation function 1 (AF-1) region, the highly conserved DNA-binding domain (DBD), a hinge region and a relatively conserved ligand-binding domain (LBD) containing an additional ligand-dependent activation function (AF-2) region (Giguère et al. 1986, Kumar et al. 1987, Mangelsdorf et al. 1995, Faus \& Haendler 2006, Griekspoor et al. 2007, Aagaard et al. 2011). Generally, unliganded AR, GR and MR are found in the cytoplasm, the ER and PR-A predominantly in the nucleus (Li et al.
2005, Yen et al. 2015), while PR-B is distributed between the cytoplasm and the nucleus (Li et al. 2005, Griekspoor et al. 2007). Unliganded steroid receptors are associated with chaperone proteins such as heat shock protein (Hsp)90 and Hsp70 (Pratt \& Toft 1997), but dissociate from the chaperone proteins upon ligand binding, as the steroid receptors undergo a conformational change (Griekspoor et al. 2007). The ligand-bound cytoplasmic steroid receptor can then enter the nucleus (Griekspoor et al. 2007), where it generally binds as a dimer to semi-palindromic DNA sequences known as hormone response elements (HREs) to activate target gene expression (transactivation) (Faus \& Haendler 2006, Aagaard et al. 2011) or as a monomer to negative HREs (nHREs) or other DNA-bound transcription factors such as nuclear factor kappa B (NFkB), to repress target gene expression (transrepression) (reviewed in (Faus \& Haendler 2006)). Steroid hormones can also elicit non-genomic effects either by binding to membranebound receptors to activate signaling cascades, which ultimately result in the downstream regulation of gene expression or by interacting with membrane kinases to activate rapid signaling pathways (Faus \& Haendler 2006, Hammes \& Levin 2007, Bennett et al. 2010, Krug et al. 2011, Yang et al. 2011, Vernocchi et al. 2013, Diep et al. 2015, Schwartz et al. 2016).

The ER, PR, AR and GR are expressed in most breast cancers, and it is therefore not surprising that they all play functional roles in breast cancer cell biology (reviewed in (Sikora 2016)). Moreover, emerging evidence suggests that their signaling pathways are not always distinct but are in fact extensively intertwined. This too is not surprising considering the high degree of homology between the steroid hormone receptors and their cognate DNA-binding sites (Giguère et al. 1986, Kumar et al. 1987, Mangelsdorf et al. 1995, Faus \& Haendler 2006, Griekspoor et al. 2007, Aagaard et al. 2011, Need et al. 2012). In the following sections, we summarize the role of steroid receptors and their interplay in breast cancer, with a focus on the known effects of the estrogens and progestogens via the ER and $\mathrm{PR}$, respectively.

\section{Estrogens and the ER}

The first association between estrogen signaling and breast cancer can be traced back to 1896 (Beatson 1896) and since then copious in vivo and in vitro studies have shown that estrogens promote breast cancer development and progression (Lippman et al. 1977, Soto \& Sonnenschein 1985, Reddel \& Sutherland 1987, Clemons \& Goss 2001, Gutendorf \& Westendorf 2001, Frasor et al. 2003, Lippert 
Table 4 Binding of hormones to transport proteins. ${ }^{a}$

\begin{tabular}{|c|c|c|c|c|c|}
\hline & SHBG (\%) & CBG (\%) & Albumin (\%) & Free $(\%)$ & Available (\%) \\
\hline \multicolumn{6}{|c|}{ Estrogens } \\
\hline $\mathrm{E}_{2}$ & 37 & 0 & 61 & 2 & 63 \\
\hline $\mathrm{E}_{3}$ & 1 & 0 & 91 & 8 & 99 \\
\hline $\mathrm{E}_{1}$ & 16 & 0 & 80 & 4 & 84 \\
\hline EE & 0 & 0 & 99 & 1 & 100 \\
\hline \multicolumn{6}{|c|}{ Progestogens } \\
\hline $\mathrm{P}_{4}$ & 0.6 & $17.7-36$ & $79.3-90.3$ & $0-2.4$ & 81.7-92.7 \\
\hline MPA & 0 & 0 & 88 & 12 & 100 \\
\hline NET & 35.5 & 0 & 60.8 & 3.7 & 64.5 \\
\hline LNG & $47.5-73.6$ & 0 & $25.5-50$ & $0-2.5$ & 26.4-52.5 \\
\hline DRSP & 0 & 0 & $95-97$ & $3-5$ & 100 \\
\hline
\end{tabular}

aDunn et al. (1981), Hammond et al. (1982), Kuhl (1990), Kuhnz et al. (1990, 1992, 1994), Schindler et al. (2003), Stanczyk et al. (2013).

CBG, corticosteroid-binding globulin; DRSP, drospirenone; $E_{1}$, estrone; $E_{2}$, estradiol; $E_{3}$, estriol; EE, ethinylestradiol; LNG, levonorgestrel; MPA, medroxyprogesterone acetate; NET, norethisterone; $\mathrm{P}_{4}$, progesterone; SHBG, sex-hormone-binding globulin.

et al. 2003, Mueck et al. 2003, Yager \& Davidson 2006, Watson et al. 2008, Fernandez \& Russo 2010, Liu et al. 2015, de Almeida Chuffa et al. 2017). Although the precise mechanisms whereby estrogens promote breast cancer is still an area of ongoing research, it is well established that ER-A is crucial for $E_{2}$-induced breast cancer cell growth (Couse \& Korach 1999, Brisken et al. 2010). This critical role for ER-A was highlighted by a study showing that $\mathrm{E}_{2}$ exposure did not cause breast cancer tumor formation in ER-A-knockout mice (reviewed in (Couse \& Korach 1999, Brisken et al. 2010)). Considering that the ER is expressed in approximately $75 \%$ of breast cancers, current therapies target ER activity or the synthesis of endogenous estrogen (Lanari et al. 2012, Lim et al. 2016, Doan et al. 2017). For example, tamoxifen or fulvestrant are used to antagonize ER-A signaling by blocking or degrading the ER respectively (Santen et al. 2009, Lanari et al. 2012, Lim et al. 2016, McNamara et al. 2016, Doan et al. 2017), while aromatase inhibitors are used to decrease the production of endogenous estrogens by inhibiting the metabolism of testosterone and androstenedione to $\mathrm{E}_{2}$ and $\mathrm{E}_{1}$, respectively.

Estrogens and ER signaling lead to the development and progression of breast cancer largely through the regulation of gene expression (Preston-Martin et al. 1990, Dickson \& Lippman 1995, Clemons \& Goss 2001, Frasor et al. 2003, Yue et al. 2013, Deroo \& Korach 2014, Luo et al. 2016). For example, $\mathrm{E}_{2}$ treatment of the MCF-7 breast cancer cell line results in the upregulation of genes encoding growth factors such as insulin-like growth factor (IGF)-binding proteins and vascular endothelial growth factorvascul (VEGF) (Dickson \& Lippman 1995, Ruohola et al. 1999, Mueller et al. 2000, Frasor et al. 2003, Garvin et al. 2006, Walker et al. 2007). Furthermore, genes regulating the cell cycle such as CCND1, CCNA2 and cyclin-dependent kinase 1 (CDK1) are also upregulated by $\mathrm{E}_{2}$ in MCF-7 cells, as are genes promoting proliferation such as Ki67 (Altucci et al. 1996, Frasor et al. 2003, Welboren et al. 2009). In contrast, $\mathrm{E}_{2}$ has previously been shown to downregulate the expression of genes inhibiting proliferation such as transforming growth factor beta 3 (TGFB3) (Frasor et al. 2003, Welboren et al. 2009), and genes promoting apoptosis such as CASP9 (Frasor et al. 2003). ChIP-seq analysis mapped ER-binding sites to the promoter regions of the CCND1, CCNA2, CDK1, Ki67 and TGFB3 genes in response to $\mathrm{E}_{2}$ treatment (Welboren

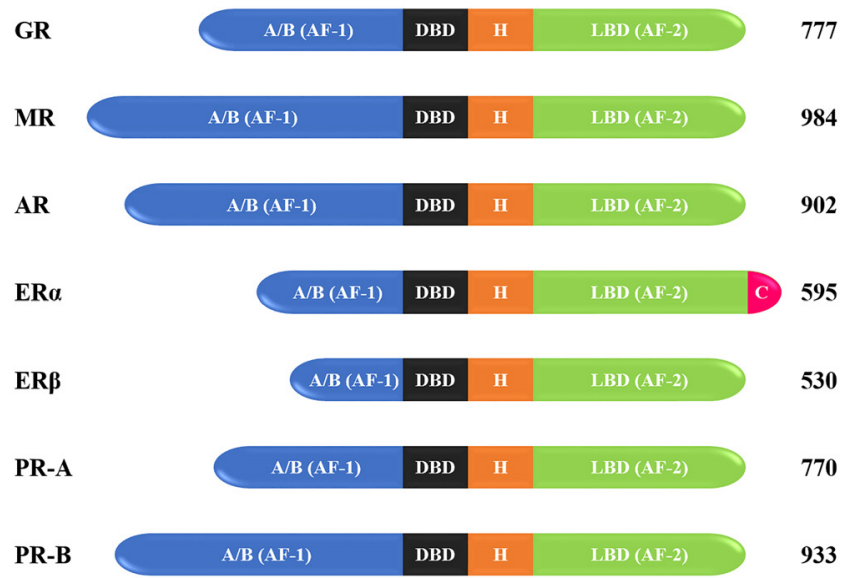

Figure 2

A simplified representation of the structure of steroid hormone receptors. These receptors contain a variable $\mathrm{N}$-terminal domain (A/B) containing the ligand-independent activation function 1 (AF-1) region, a highly-conserved DNA-binding domain (DBD), a hinge region $(H)$ enabling flexibility, and a relatively conserved ligand-binding domain (LBD) containing the ligand-dependent activation function (AF-2) region. $E R \otimes$ contains an additional C-terminal domain (C) of which the function is not known. The numbers indicated on the right represent the number of amino acids constituting each steroid receptor. Figure adapted from (Griekspoor et al. 2007).. A full color version of this figure is available at https://doi.org/10.1530/JME-18-0094. 
et al. 2009), highlighting the role of the ER in mediating the tumor-promoting effects of $\mathrm{E}_{2}$. However, the ER subtypes, ER-A and ER-B, are known to play different roles in breast cancer (Kuiper et al. 1996, Barkhem et al. 1998, Lazennec et al. 2001, Pettersson \& Gustafsson 2001, Platet et al. 2004, Strom et al. 2004, Chang et al. 2006, Boothby \& Doering 2008, Treeck et al. 2010, Lattrich et al. 2013, Leygue \& Murphy 2013). For example, ER-A has been shown to promote breast cancer pathogenesis by upregulating the expression of cyclin D1, while ER-B inhibited its expression (Liu et al. 2002). Interestingly, the role of ER-B is dependent on whether ER-A is expressed or not. In the presence of ER-A, ER-B can inhibit ER-Adriven proliferation, while in the absence of ER-A, ER-B promotes proliferation (Kuiper et al. 1996, Barkhem et al. 1998, Lazennec et al. 2001, Pettersson \& Gustafsson 2001, Platet et al. 2004, Strom et al. 2004, Chang et al. 2006, Boothby \& Doering 2008, Treeck et al. 2010, Lattrich et al. 2013, Leygue \& Murphy 2013). The differential action of the ER subtypes may in part be due to the regulation of subtype-specific target genes (Kian Tee et al. 2003, Monroe et al. 2003, Platet et al. 2004, Stossi et al. 2004, Chang et al. 2006, Zhao et al. 2008, Paruthiyil et al. 2009), possibly due to differences in the $\mathrm{N}$ - and C-terminals of ER-A and ER-B (Arnal et al. 2017). In addition, ER-B has been shown to downregulate the transcriptional activity of ER-A by modulating the recruitment of transcription factors required by the ER-A transcription complex and by increasing ER-A degradation (Matthews et al. 2006). While ER-B is expressed in lobular breast cancers and a subgroup of triple-negative breast cancers (TNBC), its expression is lost early in ductal breast cancer (reviewed in (Warner et al. 2017)). Although the precise role of ER-B in TNBC is not known, it is thought to be a potential target for treating this breast cancer subtype. For example, it has been shown that postmenopausal women with TNBC respond to tamoxifen treatment due to high expression levels of ER-B (Honma et al. 2008). Furthermore, tamoxifen decreased cell growth and increased apoptosis in the ER-A-negative SK-BR-3 breast cell line transfected with ER-B (Treeck et al. 2008). Moreover, the use of ER-B selective agonists has been suggested as treatment for the vascular symptoms experienced by menopausal women (Warner et al. 2017). The reason for this suggestion is twofold: (i) the hypothesis that vascular effects in menopause are due to increased activin and follicle-stimulating hormone ( $\mathrm{FSH}$ ) levels because of decreased endogenous $\mathrm{E}_{2}$ levels and (ii) the observation that ER-B selective agonists increase ER-B expression. ER-B regulates inhibin, which directly inhibits activin and subsequently FSH, suggesting that ER-B selective agonists could effectively decrease the vascular symptoms of menopause (reviewed in (Warner et al. 2017)).

In addition to the full-length ER subtypes, several ER splice variants have been identified in various cell lines; however, it is not clear whether all of these variants are also expressed in tissue and whether they are functional proteins (reviewed in (Heldring et al. 2007)). An ER-A 46 splice variant which lacks part of the N-terminal domain has in fact been detected in breast tumor tissue, but its function is still unknown (reviewed in (Arnal et al. 2017)). In contrast, several ER-B splice variants are expressed in breast tissue and have been shown to differentially regulate estrogen signaling (Flouriot 2000, Matthews \& Gustafsson 2003, Ramsey et al. 2004, Wang et al. 2005, Leung et al. 2006). For example, the ER-B cx splice variant contains a unique sequence in its LBD and although it cannot bind ligand, it forms heterodimers with ER-A, preventing ER-A from activating gene expression (Ogawa et al. 1998). In contrast, a second ER-B splice variant which also cannot bind ligand, forms dimers with either ER-A or ER-B, blocking their activity (Maruyama et al. 1998).

From the above, it is clear that the role of $\mathrm{E}_{2}$ and the ER subtypes in breast cancer is complex. An added complexity is the fact that many different estrogens are used in HT, and it is not clear whether these estrogens will elicit similar effects to $E_{2}$ on breast cancer. Studies directly comparing the effects of different estrogens on hallmarks of breast cancer such as cell proliferation, migration, invasion and apoptosis are scarce. The limited studies that are available suggest that while both CEE and $\mathrm{E}_{2}$ increase proliferation, $\mathrm{E}_{2}$ increased proliferation to a greater extent (Mueck et al. 2003, Wood et al. 2008). Furthermore, at least three studies have directly compared the proliferative effects of $\mathrm{E}_{1}, \mathrm{E}_{2}$ and $\mathrm{E}_{3}$ and although all studies showed that these estrogens increase breast cancer cell proliferation, differences were observed (Lippman et al. 1977, Gutendorf \& Westendorf 2001, Lippert et al. 2003). For example, our recent study (Perkins et al. 2017) and that of Gutendorf and coworkers (Gutendorf \& Westendorf 2001) reported potencies in the picomolar range and showed that $\mathrm{E}_{2}$ was more potent than $E_{3}$, while $E_{1}$ was the least potent. In contrast, Lippman and coworkers (Lippman et al. 1977) reported potencies in the nanomolar range and showed that $\mathrm{E}_{2}$ and $\mathrm{E}_{1}$ were equipotent, and more potent than $\mathrm{E}_{3}$. From these studies, it is evident that $\mathrm{E}_{2}$ is the most potent estrogen; yet, it is not clear how the proliferative effects of $\mathrm{E}_{1}$ and $\mathrm{E}_{3}$ compare to $\mathrm{E}_{2}$. A study by Lippert and coworkers (Lippert et al. 2003) comparatively investigated the effects of $E_{2}, E_{3}$ and $E_{1}$ on proliferation, and although they did 
not determine potencies, showed no significant difference in the proliferative effects of $10 \mathrm{nM}$ or $100 \mathrm{nM} \mathrm{E}_{1}, \mathrm{E}_{2}$ and $\mathrm{E}_{3}$ and showed that while $\mathrm{E}_{3}$ also stimulated proliferation at $1 \mu \mathrm{M}$ and $10 \mu \mathrm{M}, \mathrm{E}_{2}$ inhibited proliferation and $\mathrm{E}_{1}$ had no effect. Interestingly, results investigating the proliferative effects of the synthetic estrogen, $\mathrm{EE}$, relative to $\mathrm{E}_{2}$, are contradictory. While we recently showed that EE was less potent than $\mathrm{E}_{2}$, one other study of almost 20 years ago showed that $\mathrm{EE}$ was as potent as $\mathrm{E}_{2}$ (Gutendorf \& Westendorf 2001). It is thus evident that further comparative studies are required to clarify this ambiguity. To the best of our knowledge, studies investigating the effects of estrogens on migration, invasion and apoptosis only focused on $E_{2}$ and while most studies showed increased migration (Zheng et al. 2011, Shang et al. 2015) and invasion (Albini et al. 1986, Thompson et al. 1988, van den Brûle et al. 1992, Zheng et al. 2011, Jiang et al. 2013, Tchafa et al. 2013, Shang et al. 2015), as well as decreased apoptosis (Wang \& Phang 1995, Song et al. 2001, Fernando \& Wimalasena 2004, Kampa et al. 2005, Tchafa et al. 2013) in the ER-A-positive MCF-7 and T47D breast cancer cell lines, a recent study showed that $\mathrm{E}_{2}$ repressed invasion in the ER-A-positive T47D and BT474 cell lines (McFall et al. 2018). In terms of metastasis, we have shown that $E_{2}, E_{3}$, $\mathrm{E}_{1}$ and EE promote the anchorage-independent growth of the MCF-7 BUS cell line to the same extent, suggesting that there is no difference in the metastatic potential of these estrogens.

In terms of gene expression, we and two other studies have directly compared $\mathrm{EC}_{50}$ values of $\mathrm{E}_{2}, \mathrm{E}_{3}, \mathrm{E}_{1}$ and $\mathrm{EE}$ for both ER-A- and and ER-B-mediated transactivation (Bovee et al. 2004, Escande et al. 2006, Perkins et al. 2017); however, the $\mathrm{EC}_{50}$ values between the studies differed by up to 750-fold for some estrogens. Although these studies found that $\mathrm{E}_{2}$ and $\mathrm{EE}$ were the most potent estrogens, $\mathrm{E}_{3}$ was the least potent estrogen in one study (Bovee et al. 2004), while we and one other study found that $\mathrm{E}_{1}$ was the least potent (Escande et al. 2006, Perkins et al. 2017). These discrepancies may be due to the different model systems or promoter-reporter constructs used, as the first study used yeast cells and a p406-CYC1 yeast expression vector containing two estrogen response elements (EREs) (Bovee et al. 2004), one study used a cell line-derived from HeLa cells and stably expressing a plasmid containing one ERE (HELN cells) (Escande et al. 2006), while we used the MCF-7 BUS cell line (Perkins et al. 2017). In addition to transactivation of gene expression, the estrogen-bound ER can also transrepress gene expression; however, there is a paucity of studies characterizing this mechanism of action. At least two studies have investigated the efficacy and potency of $\mathrm{E}_{2}$ and/or EE for transrepression of gene expression via ER-A (Cerillo et al. 1998, Harnish et al. 2000). However, little was known for other estrogens used in HT or for the transrepressive activities via ER-B until our recent study revealed that $\mathrm{E}_{2}, \mathrm{E}_{3}, \mathrm{E}_{1}$ and $\mathrm{EE}$ have similar efficacies for transrepression via ER-A and ER-B (Perkins et al. 2017). While the potencies of these estrogens were mostly similar, $\mathrm{E}_{1}$ was more potent via ER-A, EE more potent via ER-B and $\mathrm{E}_{3}$ less potent in a model endogenously expressing both ER-A and ER-B (Perkins et al. 2017). Considering the scarcity of comparative studies and the fact that our recent study was the first to compare the effects of bioidentical hormones to the endogenous human hormones or synthetic estrogens such as EE, it is imperative that more molecular studies are conducted. This is critical considering that some of the estrogens used in HT and bHT have not been tested in large-scale, double-blinded clinical trials and their safety and efficacy is unknown.

\section{Progestogens and the PR}

The role of progestogens including natural $\mathrm{P}_{4}$ and progestins in breast cancer is not straightforward. Some progestins have been associated with increased breast cancer risk (Writing Group for the Women's Health Initiative Investigators 2002, Million Women Study Collaborators 2003, Fournier et al. 2008a, Marjoribanks et al. 2017), while others and $\mathrm{P}_{4}$ have not (Nachtigall et al. 1979, Obel et al. 1993, Herrington et al. 2000, Hulley et al. 2002, Waters et al. 2002, Greenspan et al. 2005, Veerus et al. 2006, Fournier et al. 2008a, Tierney et al. 2009, Schierbeck et al. 2012). In addition, results from in vitro studies investigating the effects of progestogens on breast cancer cell proliferation are also contradictory. For example, while some studies have shown that $\mathrm{P}_{4}$ (Carvajal et al. 2005), R5020 (Hissom \& Moore 1987, Moore et al. 2000), MPA (Franke \& Vermes 2003, Werner et al. 2005) and NET-A (Schoonen et al. 1995, Franke \& Vermes 2003, Werner et al. 2005) promote proliferation of the MCF-7, ZR75 or T47D breast cancer cell lines, others have shown that these progestogens are anti-proliferative in the T47D cell line (Horwitz \& Freidenberg 1985, Musgrove et al. 1991, Botella et al. 1994, Groshong et al. 1997, Formby $\&$ Wiley 1999). Some studies have even suggested that $\mathrm{P}_{4}$ and the progestin ORG 2058 are proliferative for one cell cycle, after which they exert anti-proliferative and pro-apoptotic effects (Musgrove et al. 1991, Groshong et al. 1997). Interestingly, the effects of progestogens on proliferation also seem to be dependent on the absence 
or presence of estrogen. For example, while progestogens such as $\mathrm{P}_{4}$, MPA, NET, LNG, GES and R5020, have been shown to promote proliferation of the MCF-7 cell line, they exerted anti-proliferative effects in the presence of $\mathrm{E}_{2}$ (Schoonen et al. 1995). Investigations into the effects of the progestogens on other hallmarks of breast cancer such as apoptosis, migration and invasion are scarce, and results from the limited studies are ambiguous. For example, some studies suggest that $\mathrm{P}_{4}$ (Franke \& Vermes 2003, Werner et al. 2005), MPA and NET increase apoptosis (Werner et al. 2005), while others suggest that these progestogens inhibit apoptosis (Ory et al. 2001, Franke \& Vermes 2003, Moore et al. 2006). While it has also been shown that $\mathrm{P}_{4}$, MPA, NES and DRSP can promote migration (Fu et al. 2008, 2010, Diaz et al. 2012) and invasion (Kato et al. 2005, Fu et al. 2008, 2010) in the T47D (Fu et al. 2008, 2010) and ZR75 (Kato et al. 2005, Diaz et al. 2012) breast cancer cell lines, MPA was found to promote migration and invasion of the T47D cell line to a greater extent than $\mathrm{P}_{4}$, NES and DRSP (Fu et al. 2008). Interestingly, $\mathrm{P}_{4}, \mathrm{NES}$ and DRSP, unlike MPA, reduced $\mathrm{E}_{2}$-induced invasion but not migration (Fu et al. 2008). Furthermore, in vivo studies have shown that $\mathrm{P}_{4}, \mathrm{MPA}$, NET and LNG promote the progression of T47D and/or BT-474 human breast cancer cell xenografts in nude mice (Liang et al. 2007, 2010), via a mechanism requiring expression of the potent angiogenic growth factor VEGF, a protein implicated in the progression of tumor growth and metastasis (Hyder et al. 2001, Liang et al. 2007, 2010). Moreover, at least one study has shown that both $\mathrm{P}_{4}$ and MPA reactivate stem cell-like properties in pre-existing breast cancer stem cells (Horwitz \& Sartorius 2008), supporting the idea that these progestogens reactivate dormant breast cancer cells or potentiate the effects of small, previously undetectable cancers (Horwitz \& Sartorius 2008, Eden 2011). In further support of progestins promoting the progression of already established tumors, a recent study showed that MPA increased the expression of CD44 and the activity of aldehyde dehydrogenase, known markers of cancer stem cells, in BT-474 and/or T47D breast cancer cells (Goyette et al. 2017). In light of the above, it is clear that more molecular studies are needed, particularly studies directly comparing the effects of the progestogens on hallmarks of breast cancer and the physiology of mammary stem cells. It is well known that $\mathrm{P}_{4}$ elicits its biological effects primarily by binding to the PR (Grimm et al. 2016) and that progestins were designed to mimic the actions of $\mathrm{P}_{4}$ also by binding to the PR (Sitruk-Ware 2004, SitrukWare \& Nath 2010). However, it is known that some progestins can also bind to and elicit biological effects via steroid receptors other than the $\mathrm{PR}$, such as the $\mathrm{AR}$ (Africander et al. 2014, Louw-du Toit et al. 2017) and GR (Koubovec et al. 2005). Thus, whether the observed effects of the progestogens on proliferation and other hallmarks of breast cancer are mediated by the PR, or any of the other steroid receptors, is still an area of ongoing research. However, at least one study has provided evidence that PR knockdown using siRNA (Wargon et al. 2015) abrogates MPA-induced breast cancer cell proliferation.

Three PR isoforms, PR-A, PR-B and PR-C, transcribed from different promoters of a single gene, have been identified (Kastner et al. 1990, Diep et al. 2015). However, only PR-A and PR-B are functional as PR-C lacks a DBD, and thus, cannot bind to DNA to activate gene transcription (Condon et al. 2006, Diep et al. 2015). Interestingly, approximately $65 \%$ of $\mathrm{P}_{4}$-regulated genes are regulated only by PR-B, while approximately $4 \%$ are regulated only by PR-A and $25 \%$ are regulated by both PR isoforms (Richer et al. 2002, Lanari et al. 2012). These somewhat unique gene sets result in different biological roles for PR-A and PR-B, where PR-B mediates $\mathrm{P}_{4}$-induced normal breast cell proliferation (Conneely et al. 2003, MulacJericevic et al. 2003), while $\mathrm{P}_{4}$-bound PR-A is implicated in maintaining ovarian and uterine functions (Conneely et al. 2003, Mulac-Jericevic et al. 2003, Lanari et al. 2012). The transcriptional activity of the individual isoforms is also cell specific and is extensively regulated by posttranslational modifications including phosphorylation, sumoylation, acetylation and ubiquitination (reviewed in Diep et al. 2015). However, PR-A is generally more transcriptionally active than PR-B in the absence of ligand (Jacobsen et al. 2002), while PR-B is more transcriptionally active in the presence of agonist (Faivre \& Lange 2007, Lanari et al. 2012). The latter may be due to the additional AF-3 region in the N-terminal domain of PR-B, which enables the binding of cofactors to PR-B that cannot bind PR-A (Giangrande et al. 1997).

The PR is a well-known ER-target gene and is thus expressed in most ER-A-positive breast tumors (Horwitz et al. 1978, Kastner et al. 1990, Dunbier et al. 2010). Although traditionally thought of only as an indicator of active ER signaling pathways in breast cancer tumors, the role of the PR in breast cancer is quite complex and dependent on multiple factors such as the relative ratio of PR-A to PR-B (Diep et al. 2015). PR-A and PR-B are generally expressed at equimolar ratios in the normal mammary gland (Mote et al. 2002), resulting in the formation of PR-A/B heterodimers that regulate a specific gene set (reviewed in Lanari et al. 2012). In contrast, PR-A and/or PR-B expression is often increased in 
atypical breast lesions, dysregulating the ratio of the PR isoforms (Graham et al. 1995). This dysregulation disrupts normal PR signaling due to the predominance of one PR isoform and the subsequent formation of homodimers that regulate a unique gene set (reviewed in Lanari et al. 2012). Interestingly, PR-A is upregulated in most ductal carcinomas in situ and invasive breast cancers (Graham et al. 1995, Mote et al. 1999, 2002) and is thought to be more stable than PR-B (Faivre \& Lange 2007). Although the exact mechanism behind this has not been fully elucidated (Faivre \& Lange 2007), it may be due to the fact that PR-B contains six more phosphorylation sites in its $\mathrm{N}$-terminal domain than PR-A, and the increased kinase activity in pre- or early-malignant breast tissue drives PR-B phosphorylation resulting in both PR-B hyperactivity and degradation (Dressing \& Lange 2009, Dressing et al. 2009). Moreover, the activity of PR-B, as well as the ER, AR, GR and MR, can also be repressed by PR-A under normal cellular conditions (Vegeto et al. 1993, McDonnell \& Goldman 1994, McDonnell et al. 1994, Kraus et al. 1995, 1997, Lim et al. 1999, Conneely \& Lydon 2000, Li et al. 2005, Griekspoor et al. 2007), suggesting crosstalk between steroid receptors. Interestingly, steroid receptor crosstalk mechanisms have been described in the breast cancer context.

\section{Interplay between ER-A and the PR}

Recent evidence in the literature suggests that crosstalk between ER-A and the PR plays an important role in breast cancer pathogenesis (Giulianelli et al. 2012, Daniel et al. 2015, Mohammed et al. 2015, Singhal et al. 2016). For example, it has been suggested that the potent PR agonist, R5020, promotes breast cancer progression by activating kinase cascades via a mechanism requiring both ER-A and the PR (Migliaccio et al. 1998, Ballare et al . 2003). Furthermore, Giulianelli et al. (2012) provided evidence of an interaction between ER-A and the PR in breast cancer tissue and cell lines and showed that this interaction is required for MPA-induced breast cancer gene expression and cell proliferation in the T47D breast cancer cell line. Subsequent studies have revealed that the PR can modulate the transcriptional activity and chromatin localization of ER-A through the formation of these ER-A-PR complexes (Giulianelli et al. 2012, Daniel et al. 2015, Mohammed et al. 2015, Singhal et al. 2016). For example, Daniel and coworkers (Daniel et al. 2015) showed that the unliganded PR can act as a molecular scaffold, resulting in PR, ER-A, PELP-1 (proline-, glutamic acid- and leucine-rich protein 1) and IGF1 complexes that alter ER-A gene regulation leading to a more aggressive proliferative response upon $\mathrm{E}_{2}$ stimulation of the MCF-7 cell line. A second study by Mohammed et al. (2015) showed that $\mathrm{P}_{4^{-}}$or R5020-bound PR is recruited to the ER-A complex in both MCF-7 and T47D cells and redirects $\mathrm{E}_{2}$-activated ER-A chromatin binding such that the gene expression profile is similar to that of PR alone. A similar mechanism was shown by Singhal et al. (2016) in primary ER-A- and PR-positive human tumors and is reported to lead to decreased proliferation and an improved clinical outcome (Mohammed et al. 2015). The above-mentioned studies suggest that an interaction between ER-A and the PR can be associated with either poor or good prognosis in breast cancer and that the outcome is determined by the absence or presence of PR ligands. Whether this is true for all PR ligands is not known. This is particularly important for progestins used in HT as some progestins from the earlier generations have been implicated in increased breast cancer risk, while clinical trials implicating newergeneration progestins that have a greater affinity for the PR and elicit biological effects more similar to $P_{4}$ than progestins from the earlier generations (Sitruk-Ware 2004, Sitruk-Ware \& Nath 2010, Africander et al. 2011), are mostly lacking. Further studies are thus required to elucidate the role of ER-A-PR crosstalk in breast cancer pathogenesis in response to different progestins. An added complexity in delineating the role of ER-PR crosstalk in response to progestins is the fact that although a few studies report that some progestins and/or their metabolites may bind to the ER (Larrea et al. 2001, Pasapera et al. 2002, Escande et al. 2006, Lemus et al. 2009, Louw-du Toit et al. 2017), conflicting results are often reported, and most of these studies fail to differentiate between the ER subtypes. In a recent study, we have compared the binding of $\mathrm{P}_{4}$, MPA, NET-A, LNG, GES, NES, DRSP and NoMAC to the individual ER subtypes and showed that only NET-A, LNG and GES, which are all derived from testosterone, bind to ER-A, while none of the progestogens bind to ER-B (Louw-du Toit et al. 2017). Interestingly, it has previously been shown that ER-A is required at least for MPA-induced breast cancer cell proliferation (Giulianelli et al. 2012); thus, studies investigating the estrogenic activity of progestins used in HT and whether ER-A is required for the effects of all progestins on proliferation are needed. Furthermore, considering that the ER-B subtype is also expressed in breast cancers, investigations are required to determine whether a similar interaction occurs between ER-B and the PR and what the implications of such an interaction would be. Current molecular studies investigating the role of ER-B in breast cancer cell 
biology are however limited, likely due to the lack of an effective commercial antibody for this ER subtype (Nelson et al. 2017). A better understanding of the role of ER-PR crosstalk, and whether it is involved in the increased breast cancer risk associated with some progestins, may help with the design of a progestin that can be used in HT without breast cancer risk.

\section{Interplay between the ER and AR}

A number of studies have suggested that androgens and the AR play a critical role in breast cancer biology (reviewed in Dimitrakakis \& Bondy 2009, Hickey et al. 2012, McNamara et al. 2014, Tarulli et al. 2014, Rahim \& O'Regan 2017) and considering that the AR is expressed in about $90 \%$ of primary breast tumors (reviewed in Hickey et al. 2012), it is not surprising that AR-targeted treatment for breast cancer is actively being investigated. However, the precise role of the AR in breast cancer is dependent on whether ER-A is present. While the AR generally plays an anti-proliferative role in ER-A-positive breast tumors by inhibiting the activity of ER-A (Dauvois et al. 1991, de Launoit et al. 1991, Hackenberg et al. 1991, Birrell et al. 1995a, Ortmann et al. 2002, Greeve et al. 2004, Peters et al. 2009), the AR can also mimic the role of the ER-A in ER-A-negative breast cancers and promote breast cancer development (reviewed in Rahim \& O'Regan 2017). As a result, clinical trials are currently evaluating the use of selective AR modulators in ER-A-positive breast cancer therapies, and anti-androgens for use in ER-A-negative breast cancer therapies (Rahim \& O'Regan 2017). One suggested mechanism whereby the AR can attenuate the activity of ER-A is by displacing ER-A from ER-binding sites, either via binding to androgen response elements that are in close proximity to ER-binding sites in estrogen target genes or by competing with ER-A for binding directly to EREs in target genes (Peters et al. 2009, Need et al. 2012). Another mechanism may be an AR-mediated increase in ER-B expression, which is known to inhibit the activity of ER-A, as increased ER-B expression has previously been shown in the presence of natural dihydrotestosterone (DHT) and the synthetic androgen mibolerone in MCF-7 and ZR75 breast cancer cell lines (Rizza et al. 2014).

Interestingly, it has been shown that the firstgeneration progestin MPA is a potent AR agonist (Africander et al. 2014, Louw-du Toit et al. 2017), and that like DHT, it inhibited the transcriptional activity of ER-A in MDA-MB-231 breast cancer cells overexpressing ER-A and the AR (Peters et al. 2009). However, AR-mediated effects in breast cancer appear to be a double-edged sword.
For example, MPA treatment has effectively been used to treat breast cancer (Birrell et al. 1995b) via a mechanism that potentially promotes AR-induced apoptosis. In contrast, MPA used in HT has been associated with increased breast cancer risk (Writing Group for the Women's Health Initiative Investigators 2002, Million Women Study Collaborators 2003, Fournier et al. 2008a) by a mechanism possibly involving the disruption of normal AR signaling (Kemppainen et al. 1999, Carroll et al. 2016). As some progestins can bind to the AR and elicit androgenic effects, while others elicit anti-androgenic effects, it is important to determine the progestin agonist and antagonist properties for AR-mediated transactivation and transrepression of target genes in the same model system. We have performed these experiments for $\mathrm{P}_{4}$, MPA, NET-A, LNG, GES, NES, DRSP and NoMAC, and showed that the first (MPA, NET-A), second (LNG) and third-generation progestins (GES) display potent AR agonist activity, similar to that of DHT, for transactivation and transrepression of gene expression (Africander et al. 2014, Louw-du Toit et al. 2017). In contrast, like $\mathrm{P}_{4}$, the fourth-generation progestins elicit anti-androgenic activity, similar to that of the well-known AR antagonist hydroxyflutamide (Louw-du Toit et al. 2017). Considering that some progestins that have been reported to increase breast cancer risk can elicit androgenic activity, studies are required to determine if ER-A-AR crosstalk plays a role in the mechanism whereby some progestins increase breast cancer risk.

\section{Interplay between the ER and the GR or MR}

Recent studies have also highlighted roles for the GR, MR and their cognate ligands in breast cancer cell biology. In terms of the GR and its ligands (glucocorticoids), both are involved in mammary gland development during puberty and pregnancy (reviewed in Vilasco et al. 2011, McNamara et al. 2017). Glucocorticoids have been shown to regulate breast cancer cell proliferation (Mattern et al. 2007, Vilasco et al. 2011, Courtin et al. 2012), invasiveness, motility and adhesiveness via GR-mediated upregulation of oncogenes and downregulation of metastasis suppressor genes (reviewed in Moutsatsou \& Papavassiliou 2007). Interestingly, although the GR is expressed in approximately 60\% of breast cancers (Abduljabbar et al. 2015), no definitive correlation has been found between GR expression and prognosis of breast cancers (reviewed in Vilasco et al. 2011). Some studies, however, suggest that its role may be context dependent as high GR expression has been associated with a good outcome in ER-A-positive 
cancers, while it is associated with a poor outcome in ER-A-negative cancers (Pan et al. 2011). For example, in ER-A-negative MDA-MB-231 cells, GR activation by dexamethasone (Dex) has been shown to increase the expression of genes involved in cell survival, such as serine/threonine protein kinase 1 (SGK1) and dual specificity protein phosphatase 1 (DUSP1) (Pan et al. 2011), while in the mouse xenograft model of MDA-MB-231 cells apoptosis induced by the chemopreventative agent, paclitaxel, was inhibited by Dex (Pan et al. 2011). In the presence of the ER, however, ER-A-GR complexes were formed when MCF-7 cells were treated with $\mathrm{E}_{2}$ and Dex (Karmakar et al. 2013, West et al. 2016) resulting in the reprogramming of ER-A- and GR-binding sites (Voss et al. 2011, Miranda et al. 2013, West et al. 2016), and the subsequent activation of genes associated with a more favorable breast cancer outcome (West et al. 2016). The reprogramming involved an assisted loading mechanism which entailed the GR altering the chromatin landscape to expose novel binding sites to which ER-A can bind (Voss et al. 2011, Miranda et al. 2013). Moreover, Dex has been shown to antagonize the proliferative effects of $\mathrm{E}_{2}$ (Zhou et al. 1989), while also inactivating estrogens by sulfation due to the activation of estrogen sulfotransferase (Gong et al. 2008, Vilasco et al. 2011). However, the converse is also true as $E_{2}$ has been shown to decrease GR expression and dephosphorylate the GR, thus inhibiting glucocorticoid action (Zhang et al. 2009, Vilasco et al. 2011). Taken together, although it is clear that the interplay between the ER and GR in breast cancer is complex, targeting of the GR as a potential for novel breast cancer therapies should not be excluded.

The MR has been shown to compensate for the absent GR during specific stages of mammary gland development (Kingsley-Kallesen et al. 2002), suggesting that the MR may play a similar role to the GR in breast cancer cell biology (Sikora 2016). Although the MR is expressed in most breast cancer tumors (Martin et al. 1984, Sasano et al. 1997, Yang \& Young 2009), little is known about its role in breast cancer pathogenesis. Nevertheless, the MR ligand, aldosterone, has been shown to increase breast cancer cell proliferation and migration via a mechanism requiring the $\mathrm{MR}$ and the G-protein estrogen receptor (GPER), also known as the G protein-coupled receptor 30 (GPR30) (Rigiracciolo et al. 2016). This suggests that the MR is also involved in crosstalk mechanisms in breast cancer. Interestingly, at least one study has shown that the MR and ER-A can form a complex in HEK293 cells transiently transfected with cDNA expression vectors for the MR and ER-A (Barrett Mueller et al. 2014), thus it is likely that a similar complex formation may be seen in breast cancer cells. Implications of this putative MR and ER-A crosstalk is not clear. Although beyond the scope of this review, both the GR and MR have also been implicated in crosstalk with the PR (Leo et al. 2004), emphasizing the importance of future studies investigating the cellular mechanisms of the GR and MR in breast cancer, as well as the extensive interactions between different members of the steroid receptor family.

\section{Conclusion}

Despite the efficacy of FDA-approved conventional HT in relieving the symptoms of menopause, its association with increased breast risk is a major concern. Although both estrogen only and estrogen-progestin HT regimens have been associated with increased breast cancer risk, findings from various clinical trials indicate that estrogen-progestin combinations are associated with a higher risk than estrogen-only HT, suggesting that the progestin component is responsible for the increased risk. These studies, however, only compared a few progestins and considering that many different progestins, some known to elicit differential effects (Hapgood et al. 2004, Stanczyk et al. 2013, Africander et al. 2014), are available it cannot be assumed that all progestins would increase breast cancer risk. However, the alarm surrounding the associated breast cancer risk has caused some women to turn to custom-compounded bHT as an alleged safer, natural alternative. Evidence to support the safety and efficacy of these bHT regimens is however lacking and has resulted in many associations including the NAMS, IMS, EMAS and Endocrine Society recommending against the use of custom-compounded bHT (de Villiers et al. 2013). Considering the large variety of hormones used in HT and bHT, and the confusion as to whether or not any of these regimens are safe in terms of breast cancer risk, or whether they initiate or promote breast cancer, it is clear that more clinical and molecular studies directly comparing their mechanism of action are needed. Molecular studies should include the determination of binding affinities, relative agonist and antagonist potencies and efficacies for transactivation and transrepression of various estrogens and progestins for individual steroid receptors. In addition, studies are required to elucidate the effects of different progestins in modulating mammary stem cells and on the reactivation of stem cell-like properties in pre-existing breast cancer stem cells. Moreover, since estrogen-progestin combination regimens are associated with a higher risk than estrogen-only regimens and that progestins elicit differential effects via steroid receptors, 
it is possible that signaling via multiple steroid receptors may contribute to the observed increased breast cancer risk. Furthermore, recent studies have revealed roles for interplay between many of the steroid receptors in breast cancer cell biology. If the extensively intertwined nature of steroid hormone receptor signaling pathways can be unraveled, it may be possible to elucidate the mechanism behind progestin-induced breast cancer and design novel progestins that do not increase breast cancer risk.

\section{Declaration of interest}

The authors declare that there is no conflict of interest that could be perceived as prejudicing the impartiality of this review.

\section{Funding}

This work was supported by the National Research Foundation (NRF) in South Africa (grant number 99114) and the Medical Research Council of South Africa.

\section{References}

Aagaard MM, Siersbæk R \& Mandrup S 2011 Molecular basis for genespecific transactivation by nuclear receptors. Biochimica et Biophysica Acta: Molecular Basis of Disease 1812 824-835. (https://doi. org/10.1016/j.bbadis.2010.12.018)

Abduljabbar R, Negm OH, Lai C-F, Jerjees DA, Al-Kaabi M, Hamed MR, Tighe PJ, Buluwela L, Mukherjee A, Green AR, et al. 2015 Clinical and biological significance of glucocorticoid receptor (GR) expression in breast cancer. Breast Cancer Research and Treatment 150 335-346. (https://doi.org/10.1007/s10549-015-3335-1)

Africander D, Verhoog N \& Hapgood JP 2011 Molecular mechanisms of steroid receptor-mediated actions by synthetic progestins used in HRT and contraception. Steroids 76 636-652. (https://doi. org/10.1016/j.steroids.2011.03.001)

Africander D, Louw R \& Hapgood JP 2013 Investigating the antimineralocorticoid properties of synthetic progestins used in hormone therapy. Biochemical and Biophysical Research Communications 433 305-310. (https://doi.org/10.1016/j.bbrc.2013.02.086)

Africander DJ, Storbeck K-H \& Hapgood JP 2014 A comparative study of the androgenic properties of progesterone and the progestins, medroxyprogesterone acetate (MPA) and norethisterone acetate (NET-A). Journal of Steroid Biochemistry and Molecular Biology 143 404-415. (https://doi.org/10.1016/j.jsbmb.2014.05.007)

Albini A, Graf J, Kitten GT, Kleinman HK, Martin GR, Veillette A, Lippman ME, Veillettet A \& Lippmant ME 1986 17ß-Estradiol regulates and v-Ha-ras transfection constitutively enhances MCF7 breast cancer cell interactions with basement membrane. PNAS 83 8182-8186. (https://doi.org/10.1073/pnas.83.21.8182)

Altucci L, Addeo R, Cicatiello L, Dauvois S, Parker MG, Truss M, Beato M, Sica V, Bresciani F \& Weisz A 1996 17beta-Estradiol induces cyclin D1 gene transcription, p36D1-p34cdk4 complex activation and p105Rb phosphorylation during mitogenic stimulation of G(1)arrested human breast cancer cells. Oncogene 12 2315-2324.

Arnal J, Lenfant F, Metivier R, Flouriot G, Henrion D, Adlanmerini M, Fontaine C, Gourdy P, Chambon P, Katzenellenbogen B, et al. 2017 Membrane and nuclear estrogen receptor alpha actions: from tissue specificity to medical implications. Physiological Reviews $\mathbf{9 7}$ 1045-1087. (https://doi.org/10.1152/physrev.00024.2016)
Ascenzi P, Bocedi A \& Marino M 2006 Structure-function relationship of estrogen receptor $\alpha$ and $\beta$ : impact on human health. Molecular Aspects of Medicine 27 299-402. (https://doi.org/10.1016/j. mam.2006.07.001)

Bachmann G, Bobula J \& Mirkin S 2010 Effects of bazedoxifene/ conjugated estrogens on quality of life in postmenopausal women with symptoms of vulvar/vaginal atrophy. Climacteric 13 132-140. (https://doi.org/10.3109/13697130903305627)

Bahamondes L \& Bahamondes MV 2014 New and emerging contraceptives: a state-of-the-art review. International Journal of Women's Health 6 221-234. (https://doi.org/10.2147/IJWH.S46811)

Ballare C, Uhrig M, Bechtold T, Sancho E, Di Domenico M, Migliaccio A, Auricchio F \& Beato M 2003 Two domains of the progesterone receptor interact with the estrogen receptor and are required for progesterone activation of the c-Src/Erk pathway in mammalian cells. Molecular and Cellular Biology 23 1994-2008. (https://doi. org/10.1128/MCB.23.6.1994-2008.2003)

Barakat RR, Bundy BN, Spirtos NM, Bell J \& Mannel RS 2006 Randomized double-blind trial of estrogen replacement therapy versus placebo in stage I or II endometrial cancer: a gynecologic oncology group study. Journal of Clinical Oncology 24 587-592. (https://doi.org/10.1200/JCO.2005.02.8464)

Barkhem T, Carlsson B, Nilsson Y, Enmark E, Gustafsson J \& Nilsson S 1998 Differential response of estrogen receptor alpha and estrogen receptor beta to partial estrogen agonists/antagonists. Molecular Pharmacology 54 105-112. (https://doi.org/10.1124/mol.54.1.105)

Barrett-Connor E, Slone S, Greendale G, Kritz-Silverstein D, Espeland M, Johnson SR, Waclawiw M \& Fineberg SE 1997 The postmenopausal estrogen/progestin interventions study: primary outcomes in adherent women. Maturitas 27 261-274. (https://doi.org/10.1016/ S0378-5122(97)00041-8)

Barrett Mueller K, Lu Q, Mohammad NN, Luu V, McCurley A, Williams GH, Adler GK, Karas RH \& Jaffe IZ 2014 Estrogen receptor inhibits mineralocorticoid receptor transcriptional regulatory function. Endocrinology 155 4461-4472. (https://doi.org/10.1210/ en.2014-1270)

Beatson G 1896 On the treatment of inoperable cases of carcinoma of the mamma: suggestions for a new method of treatment, with illustrative cases. Lancet 148 162-165. (https://doi.org/10.1016/ S0140-6736(01)72384-7)

Bennett NC, Gardiner RA, Hooper JD, Johnson DW \& Gobe GC 2010 Molecular cell biology of androgen receptor signalling. International Journal of Biochemistry and Cell Biology 42 813-827. (https://doi. org/10.1016/j.biocel.2009.11.013)

Bhavnani BR \& Stanczyk FZ 2012 Misconception and concerns about bioidentical hormones used for custom-compounded hormone therapy. Journal of Clinical Endocrinology and Metabolism 97 756-759. (https://doi.org/10.1210/jc.2011-2492)

Bhavnani BR \& Stanczyk FZ 2014 Pharmacology of conjugated equine estrogens: Efficacy, safety and mechanism of action. Journal of Steroid Biochemistry and Molecular Biology 142 16-29. (https://doi. $\operatorname{org} / 10.1016 / j . j s b m b .2013 .10 .011)$

Birrell SN, Bentel JM, Hickey TE, Ricciardelli C, Weger MA, Horsfall DJ \& Tilley WD 1995a Androgens induce divergent proliferative responses in human breast cancer cell lines. Journal of Steroid Biochemistry and Molecular Biology 52 459-467. (https://doi.org/10.1016/09600760(95)00005-K)

Birrell SN, Roder DM, Horsfall DJ, Bentel JM \& Tilley WD 1995b Medroxyprogesterone acetate therapy in advanced breast cancer: the predictive value of androgen receptor expression. Journal of Clinical Oncology 13 1572-1577. (https://doi.org/10.1200/ JCO.1995.13.7.1572)

Boothby LA \& Doering PL 2008 Bioidentical hormone therapy: a panacea that lacks supportive evidence. Current Opinion in Obstetrics and Gynecology 20 400-407. (https://doi.org/10.1097/ GCO.0b013e3283081ae9) 
Boothby LA, Doering PL \& Kipersztok S 2004 Bioidentical hormone therapy: a review. Menopause 11 356-367. (https://doi. org/10.1097/01.GME.0000094356.92081.EF)

Bosarge PM \& Freeman S 2009 Bioidentical hormones, compounding, and evidence-based medicine: what women's health practitioners need to know. Journal for Nurse Practitioners 5 421-427. (https://doi. org/10.1016/j.nurpra.2009.03.011)

Botella J, Duranti E, Duc I, Cognet AM, Delansorne R \& Paris J 1994 Inhibition by nomegestrol acetate and other synthetic progestins on proliferation and progesterone receptor content of T47-D human breast cancer cells. Journal of Steroid Biochemistry and Molecular Biology 50 41-47. (https://doi.org/10.1016/0960-0760(94)90170-8)

Bovee TFH, Helsdingen RJR, Rietjens IMCM, Keijer J \& Hoogenboom RLAP 2004 Rapid yeast estrogen bioassays stably expressing human estrogen receptors $\alpha$ and $\beta$, and green fluorescent protein: a comparison of different compounds with both receptor types. Journal of Steroid Biochemistry and Molecular Biology 91 99-109. (https://doi.org/10.1016/j.jsbmb.2004.03.118)

Bowen J, John VA, Maria E \& Rami A 1998 Bioavailability of oestradiol from the AloraTM $(0.1 \mathrm{mg} /$ day $)$ oestradiol matrix transdermal delivery system compared with Estraderm (0.1 mg/day). Journal of Obstetrics and Gynaecology 18 575-580. (https://doi.org/10.1080/ 01443619866408)

Brisken C 2013 Progesterone signalling in breast cancer: a neglected hormone coming into the limelight. Nature Reviews Cancer 13 385-396. (https://doi.org/10.1038/nrc3518)

Brisken C, Malley BO \& O'Malley B 2010 Hormone action in the mammary gland. Cold Spring Harbor Perspectives in Biology 2 a003178. (https://doi.org/10.1101/cshperspect.a003178)

Burry KA, Patton PE \& Hermsmeyer K 1999 Percutaneous absorption of progesterone in postmenopausal women treated with transdermal estrogen. American Journal of Obstetrics and Gynecology 180 1504-1511. (https://doi.org/10.1016/S0002-9378(99)70046-3)

Carey B, Carey A, Patel S, Carter G \& Studd J 2000 A study to evaluate serum and urinary hormone levels following short and long term administration of two regimens of progesterone cream in postmenopausal women. BJOG : An International Journal of Obstetrics and Gynaecology 107 722-726. (https://doi. org/10.1111/j.1471-0528.2000.tb13331.x)

Carroll JS, Hickey TE, Tarulli GA, Williams M \& Tilley WD 2016 Deciphering the divergent roles of progestogens in breast cancer. Nature Reviews Cancer 17 54-64. (https://doi.org/10.1038/nrc.2016.116)

Carvajal A, Espinoza N, Kato S, Pinto M, Sadarangani A, Monso C, Aranda E, Villalon M, Richer JK, Horwitz KB, et al. 2005 Progesterone pre-treatment potentiates EGF pathway signaling in the breast cancer cell line ZR-75. Breast Cancer Research and Treatment 94 171-183. (https://doi.org/10.1007/s10549-005-7726-6)

Cerillo G, Rees A, Manchanda N, Reilly C, Brogan I, White A \& Needham M 1998 The oestrogen receptor regulates NFkB and AP-1 activity in a cell-specific manner. Journal of Steroid Biochemistry and Molecular Biology 67 79-88. (https://doi.org/10.1016/S09600760(98)00078-8)

Chang EC, Frasor J, Komm B \& Katzenellenbogen BS 2006 Impact of estrogen receptor $\beta$ on gene networks regulated by estrogen receptor $\alpha$ in breast cancer cells. Endocrinology 147 4831-4842. (https://doi. org/10.1210/en.2006-0563)

Chatterton RT, Geiger AS, Gann PH \& Khan SA 2003 Formation of estrone and estradiol from estrone sulfate by normal breast parenchymal tissue. Journal of Steroid Biochemistry and Molecular Biology 86 159-166. (https://doi:10.1016/S0960-0760(03)00266-8)

Chaumeil JC 1998 Micronization: a method of improving the bioavailability of poorly soluble drugs. Methods and Findings in Experimental and Clinical Pharmacology 20 211-215.

Cheng GJ, Liu JL, Zhang Q, Fan W, Ye HF, Wang ZQ \& Pan HP 1993 Nylestriol replacement therapy in postmenopausal women. A threeyear prospective study. Chinese Medical Journal 106 911-916.
Cherry N, Gilmour K, Hannaford P, Heagerty A, Khan MA, Kitchener H, McNamee R, Elstein M, Kay C, Seif M, et al. 2002 Oestrogen therapy for prevention of reinfarction in postmenopausal women: a randomised placebo controlled trial. Lancet 360 2001-2008. (https:// doi.org/10.1016/S0140-6736(02)12001-0)

Chervenak J 2009 Bioidentical hormones for maturing women. Maturitas 64 86-89. (https://doi.org/10.1016/j.maturitas.2009.08.002)

Chlebowski RT, Hendrix SL, Langer RD, Stefanick ML, Gass M, Lane D, Rodabough RJ, Gilligan MA, Cyr MG, Thomson CA, et al. 2003 Influence of estrogen plus progestin on breast cancer and mammography in healthy postmenopausal women. JAMA 2893243. (https://doi.org/10.1001/jama.289.24.3243)

Cirigliano M 2007 Bioidentical hormone therapy: a review of the evidence. Journal of Women's Health 16 600-631. (https://doi. org/10.1089/jwh.2006.0311)

Clavel-Chapelon F 2015 Cohort profile: the French E3N cohort study. International Journal of Epidemiology 44 801-809. (https://doi. org/10.1093/ije/dyu184)

Clemons M \& Goss P 2001 Estrogen and the risk of breast cancer. New England Journal of Medicine 344 276-285. (https://doi.org/10.1634/ theoncologist.11-5-435)

Conaway E 2011 Bioidentical hormones: an evidence-based review for primary care providers. Journal of the American Osteopathic Association 111 153-164.

Condon JC, Hardy DB, Kovaric K \& Mendelson CR 2006 Up-regulation of the progesterone receptor (PR)-C isoform in laboring myometrium by activation of nuclear factor- $\mathrm{B}$ may contribute to the onset of labor through inhibition of PR function. Molecular Endocrinology 20 764-775. (https://doi. org/10.1210/me.2005-0242)

Conneely OM \& Lydon JP 2000 Progesterone receptors in reproduction: functional impact of the A and B isoforms. Steroids 65 571-577. (https://doi.org/10.1016/S0039-128X(00)00115-X)

Conneely OM, Lydon JP, De Mayo F \& O'Malley BW 2000 Reproductive functions of the progesterone receptor. Journal of the Society for Gynecologic Investigation 7 S25-S32. (https://doi.org/10.1177/1071557 600007001S09)

Conneely OM, Jericevic BM \& Lydon JP 2003 Progesterone receptors in mammary gland development and tumorigenesis. Journal of Mammary Gland Biology and Neoplasia 8 205-214. (https://doi. org/10.1023/A:1025952924864)

Cooper A, Spencer C, Whitehead MI, Ross D, Barnard GJ \& Collins WP 1998 Systemic absorption of progesterone from Progest cream in postmenopausal women. Lancet 351 1255-1256. (https://doi. org/10.1016/S0140-6736(05)79323-5)

Courtin A, Communal L, Vilasco M, Cimino D, Mourra N, de Bortoli M, Taverna D, Faussat A-M, Chaouat M, Forgez P, et al. 2012 Glucocorticoid receptor activity discriminates between progesterone and medroxyprogesterone acetate effects in breast cells. Breast Cancer Research and Treatment 131 49-63. (https://doi.org/10.1007/s10549011-1394-5)

Couse JF \& Korach KS 1999 Estrogen receptor null mice: what have we learned and where will they lead us? Endocrine Reviews 20 358-417. (https://doi.org/10.1210/edrv.20.3.0370)

Cummings SR, Browner WS, Bauer D, Stone K, Ensrud K, Jamal S \& Ettinger B 1998 Endogenous hormones and the risk of hip and vertebral fractures among older women. New England Journal of Medicine 339 733-738. (https://doi:10.1056/NEJM199809 103391104)

Curcio JJ, Wollner DA, Schmidt JW \& Kim LS 2006 Is bio-identical hormone replacement therapy safer than traditional hormone replacement therapy? Treatments in Endocrinology 5 367-374. (https:// doi.org/10.2165/00024677-200605060-00005)

Cuzick J 2008 Hormone replacement therapy and the risk of breast cancer. European Journal of Cancer 44 2344-2349. (https://doi. org/10.1016/j.ejca.2008.07.041) 
Daniel AR, Hagan CR \& Lange CA 2011 Progesterone receptor action: defining a role in breast cancer. Expert Review of Endocrinology and Metabolism 6 359-369. (https://doi.org/10.1586/eem.11.25)

Daniel A, Gaviglio A, Knutson T, Ostrander J, D'Assoro A, Ravindranathan P, Peng Y, Raj G, Yee D \& Lange C 2015 Progesterone receptor-B enhances estrogen responsiveness of breast cancer cells via scaffolding PELP1- and estrogen receptor-containing transcription complexes. Oncogene 34 506-515. (https://doi. org/10.1038/onc.2013.579)

Dauvois S, Geng CS, Lévesque C, Mérand Y \& Labrie F 1991 Additive inhibitory effects of an androgen and the antiestrogen EM-170 on estradiol-stimulated growth of human ZR-75-1 breast tumors in athymic mice. Cancer Research 51 3131-3135. (https://doi. org/10.1016/S0079-6123(08)81010-2)

Davis S 2015 Intervention: androgens. In Treatment of the Postmenopausal Woman: Basic and Clinical Aspects, 3rd ed., pp 799-812. Ed R Lobo. New York: Elsevier. (https://doi.org/10.1017/ CBO9781107415324.004)

de Almeida Chuffa LG, Lupi-Júnior LA, Costa AB, de Arruda Amorim JP \& Ferreira Seiva FR 2017 The role of sex hormones and steroid receptors on female reproductive cancers. Steroids 118 93-108. (https://doi.org/10.1016/j.steroids.2016.12.011)

de Launoit Y, Dauvois S, Dufour M, Simard J \& Labrie F 1991 Inhibition of cell cycle kinetics and proliferation by the androgen $5 \alpha$-dihydrotestosterone and antiestrogen N,n-butyl-N-methyl-11$\left[16^{\prime} \alpha\right.$-chloro-3',17 $\beta$-dihydroxy-estra- $1^{\prime}, 3^{\prime}, 5^{\prime}-\left(10^{\prime}\right)$ triene-7' $\alpha$-yl] undecanamide in human breast cancer ZR-7. Cancer Research $\mathbf{5 1}$ 2797-2802.

de Villiers T, Gass M, Haines C, Hall J, Lobo R, Pierroz D \& Rees M 2013 Global consensus statement on menopausal hormone therapy. Climacteric 16 203-204. (https://doi.org/10.3109/13697137.2013.771520)

Depypere HT, Bolca S, Bracke M, Delanghe J, Comhaire F \& Blondeel P 2015 The serum estradiol concentration is the main determinant of the estradiol concentration in normal breast tissue. Maturitas $\mathbf{8 1}$ 42-45. (https://doi:10.1016/j.maturitas.2015.01.014)

Deroo BJ \& Korach KS 2014 Estrogen receptors and human disease. Nature 116 561-570. (https://doi.org/10.1172/JCI27987.Selective)

Diaz J, Aranda E, Henriquez S, Quezada M, Espinoza E, Bravo ML, Oliva B, Lange S, Villalon M, Jones M, et al. 2012 Progesterone promotes focal adhesion formation and migration in breast cancer cells through induction of protease-activated receptor-1. Journal of Endocrinology 214 165-175. (https://doi.org/10.1530/JOE-11-0310)

Dickson RB \& Lippman ME 1995 Growth factors in breast cancer. Endocrine Reviews 16 559-589. (https://doi.org/10.1210/edrv-16-5-559)

Diep CH, Daniel AR, Mauro LJ, Knutson TP \& Lange CA 2015 Progesterone action in breast, uterine, and ovarian cancers. Journal of Molecular Endocrinology 54 R31-R53. (https://doi.org/10.1530/JME-14-0252)

Dietel M 2010 Hormone replacement therapy (HRT), breast cancer and tumor pathology. Maturitas 65 183-189. (https://doi.org/10.1016/j. maturitas.2009.11.005)

Dimitrakakis C \& Bondy C 2009 Androgens and the breast. Breast Cancer Research 11 212-220. (https://doi.org/10.1186/bcr2413)

Doan TB, Graham JD \& Clarke CL 2017 Emerging functional roles of nuclear receptors in breast cancer. Journal of Molecular Endocrinology 58 R169-R190. (https://doi.org/10.1530/JME-16-0082)

Dressing GE \& Lange CA 2009 Integrated actions of progesterone receptor and cell cycle machinery regulate breast cancer cell proliferation. Steroids 74 573-576. (https://doi.org/10.1016/j. steroids.2008.12.001)

Dressing GE, Hagan CR, Knutson TP, Daniel AR \& Lange CA 2009 Progesterone receptors act as sensors for mitogenic protein kinases in breast cancer models. Endocrine Related Cancer 16 351-361. (https:// doi.org/10.1677/ERC-08-0281)

Drisko JA 2000 'Natural' isomolecular hormone replacement: an evidence-based medicine approach. International Journal of Pharmaceutical Compounding 4 414-420.
Du JY, Sanchez P, Kim L, Azen CG, Zava DT \& Stanczyk FZ 2013 Percutaneous progesterone delivery via cream or gel application in postmenopausal women. Menopause 20 1169-1175. (https:// doi:10.1097/GME.0b013e31828d39a2)

Dunbier AK, Anderson H, Ghazoui Z, Folkerd EJ, A'Hern R, Crowder RJ, Hoog J, Smith IE, Osin P, Nerurkar A, et al. 2010 Relationship between plasma estradiol levels and estrogen-responsive gene expression in estrogen receptor-positive breast cancer in postmenopausal women. Journal of Clinical Oncology 28 1161-1167. (https://doi.org/10.1200/JCO.2009.23.9616)

Dunn JF, Nisula BC \& Rodbard D 1981 Transport of steroid hormones: Binding of 21 endogenous steroids to both testosterone-binding globulin and corticosteroid-binding globulin in human plasma. The Journal of Clinical Endocrinology \& Metabolism 53 58-68. (https:// doi:10.1210/jcem-53-1-58)

Eden JA 2011 Breast cancer, stem cells and sex hormones. Part 3: the impact of the menopause and hormone replacement. Maturitas 68 129-136. (https://doi.org/10.1016/j.maturitas.2010.11.005)

Eden JA, Hacker NF \& Fortune M 2007 Three cases of endometrial cancer associated with 'bioidentical' hormone replacement therapy. Medical Journal of Australia 187 244-245.

Elmlinger MW, Kühnel W \& Ranke MB 2002 Reference ranges for serum concentrations of lutropin (LH), follitropin (FSH), estradiol (E2), prolactin, progesterone, sex hormone-binding globulin (SHBG), dehydroepiandrosterone sulfate (DHEAS), cortisol and ferritin in neonates, children and young adul. Clinical Chemistry and Laboratory Medicine 40 1151-1160. (https://doi:10.1515/CCLM.2002.202)

Elshafie MAA \& Ewies AAA 2007 Transdermal natural progesterone cream for postmenopausal women: inconsistent data and complex pharmacokinetics. Journal of Obstetrics and Gynaecology 27 655659. (https://doi.org/10.1080/01443610701582727)

Enmark E \& Gustafsson J-Å 1999 Oestrogen receptors - an overview. Journal of Internal Medicine 246 133-138. (https://doi. org/10.1046/j.1365-2796.1999.00545.x)

Escande A, Pillon A, Servant N, Cravedi J-P, Larrea F, Muhn P, Nicolas JC, Cavaillès V \& Balaguer P 2006 Evaluation of ligand selectivity using reporter cell lines stably expressing estrogen receptor alpha or beta. Biochemical Pharmacology 71 1459-1469. (https://doi. org/10.1016/j.bcp.2006.02.002)

Faivre EJ \& Lange CA 2007 Progesterone receptors upregulate Wnt-1 to induce epidermal growth factor receptor transactivation and c-Srcdependent sustained activation of Erk1/2 mitogen-activated protein kinase in breast cancer cells. Molecular and Cellular Biology 27 466-480. (https://doi.org/10.1128/MCB.01539-06)

Falk RT, Gentzschein E, Stanczyk FZ, Garcia-Closas M, Figueroa JD, Ioffe OB, Lissowska J, Brinton LA \& Sherman ME 2012 Sex steroid hormone levels in breast adipose tissue and serum in postmenopausal women. Breast Cancer Research and Treatment 131 287-294. (https://doi:10.1007/s10549-011-1734-5)

Faus H \& Haendler B 2006 Post-translational modifications of steroid receptors. Biomedicine and Pharmacotherapy 60 520-528. (https://doi org/10.1016/j.biopha.2006.07.082)

Ferlay J, Soerjomataram I, Dikshit R, Eser S, Mathers C, Rebelo M, Parkin DM, Forman D \& Bray F 2015 Cancer incidence and mortality worldwide: sources, methods and major patterns in GLOBOCAN 2012. International Journal of Cancer 136 E359-E386. (https://doi.org/10.1002/ijc.29210)

Fernandez SV \& Russo J 2010 Estrogen and xenoestrogens in breast cancer. Toxicologic Pathology 38 110-122. (https://doi. org/10.1177/0192623309354108)

Fernando RI \& Wimalasena J 2004 Estradiol abrogates apoptosis in breast cancer cells through inactivation of BAD: Ras-dependent nongenomic pathways requiring signaling through ERK and Akt. Molecular Biology of the Cell 15 3266-3284. (https://doi.org/10.1091/mbc.E03-11-0823)

Files JA, Ko MG \& Pruthi S 2011 Bioidentical hormone therapy. Mayo Clinic Proceedings 86 673-680. (https://doi.org/10.4065/mcp.2010.0714) (c) 2018 Society for Endocrinology Published by Bioscientifica Ltd. Printed in Great Britain 
Flouriot G 2000 Identification of a new isoform of the human estrogen receptor-alpha (hER-alpha) that is encoded by distinct transcripts and that is able to repress hER-alpha activation function 1. EMBO Journal 19 4688-4700. (https://doi.org/10.1093/emboj/19.17.4688)

Formby B \& Wiley TS 1999 Bcl-2, survivin and variant CD44 v7-v10 are downregulated and p53 is upregulated in breast cancer cells by progesterone: inhibition of cell growth and induction of apoptosis. Molecular and Cellular Biochemistry 202 53-61. (https://doi. org/10.1023/A:1007081021483)

Fournier A, Berrino F, Riboli E, Avenel V \& Clavel-Chapelon F 2005 Breast cancer risk in relation to different types of hormone replacement therapy in the E3N-EPIC cohort. International Journal of Cancer 114 448-454. (https://doi.org/10.1002/ijc.20710)

Fournier A, Berrino F \& Clavel-Chapelon F 2008a Unequal risks for breast cancer associated with different hormone replacement therapies: results from the E3N cohort study. Breast Cancer Research and Treatment 107 103-111. (https://doi.org/10.1007/ s10549-007-9523-x)

Fournier A, Fabre A, Mesrine S, Boutron-Ruault M-C, Berrino F \& ClavelChapelon F $2008 b$ Use of different postmenopausal hormone therapies and risk of histology- and hormone receptor-defined invasive breast cancer. Journal of Clinical Oncology 26 1260-1268. (https://doi.org/10.1200/JCO.2007.13.4338)

Franke HR \& Vermes I 2003 Differential effects of progestogens on breast cancer cell lines. Maturitas 46 55-58. (https://doi. org/10.1016/j.maturitas.2003.09.019)

Frasor J, Danes JM, Komm B, Chang KCN, Lyttle CR, Katzenellenbogen BS \& Richard Lyttle C 2003 Profiling of estrogen up- and down-regulated gene expression in human breast cancer cells: insights into gene networks and pathways underlying estrogenic control of proliferation and cell phenotype. Endocrinology 144 4562-4574. (https://doi.org/10.1210/en.2003-0567)

Fu X-D, Giretti MS, Goglia L, Flamini MI, Sanchez AM, Baldacci C, Garibaldi S, Sitruk-Ware R, Genazzani AR \& Simoncini T 2008 Comparative actions of progesterone, medroxyprogesterone acetate, drospirenone and nestorone on breast cancer cell migration and invasion. BMC Cancer 8 166-180. (https://doi.org/10.1186/14712407-8-166)

Fu XD, Goglia L, Sanchez AM, Flamini M, Giretti MS, Tosi V, Genazzani AR \& Simoncini T 2010 Progesterone receptor enhances breast cancer cell motility and invasion via extranuclear activation of focal adhesion kinase. Endocrine-Related Cancer 17 431-443. (https://doi.org/10.1677/ERC-09-0258)

Fugh-berman A \& Bythrow J 2007 Bioidentical hormones for menopausal hormone therapy: variation on a theme. Society of General Internal Medicine 22 1030-1034. (https://doi.org/10.1007/ s11606-007-0141-4)

Garvin S, Nilsson UW, Huss FRM, Kratz G \& Dabrosin C 2006 Estradiol increases VEGF in human breast studied by whole-tissue culture. Cell and Tissue Research 325 245-251. (https://doi.org/10.1007/s00441006-0159-7)

Gass MLS, Stuenkel CA, Utian WH, LaCroix A, Liu JH \& Shifren JL 2015 Use of compounded hormone therapy in the United States. Menopause 22 1276-1285. (https://doi.org/10.1097/ GME.0000000000000553)

Giangrande PH, Pollio G \& McDonnell DP 1997 Mapping and characterization of the functional domains responsible for the differential activity of the A and B isoforms of the human progesterone receptor. Journal of Biological Chemistry 272 32889-32900. (https://doi.org/10.1074/jbc.272.52.32889)

Giguère V, Hollenberg SM, Rosenfeld MG \& Evans RM 1986 Functional domains of the human glucocorticoid receptor. Cell 46 645-652. (https://doi.org/10.1016/0092-8674(86)90339-9)

Giulianelli S, Vaque JP, Soldati R, Wargon V, Vanzulli SI, Martins R, Zeitlin E, Molinolo AA, Helguero LA, Lamb CA, et al. 2012 Estrogen receptor alpha mediates progestin-induced mammary tumor growth by interacting with progesterone receptors at the Cyclin D1/MYC Promoters. Cancer Research 72 2416-2427. (https://doi.org/10.1158/ 0008-5472.CAN-11-3290)

Golding C 2009 Hormone replacement therapy with bio-identical hormones.

Gong H, Jarzynka MJ, Cole TJ, Lee JH, Wada T, Zhang B, Gao J, Song WC, DeFranco DB, Cheng S-Y, et al. 2008 Glucocorticoids antagonize estrogens by glucocorticoid receptor-mediated activation of estrogen sulfotransferase. Cancer Research 68 7386-7393. (https://doi. org/10.1158/0008-5472.CAN-08-1545)

Goyette S, Liang Y, Mafuvadze B, Cook M, Munir M \& Hyder S 2017 Natural and synthetic progestins enrich cancer stem cell-like cells in hormone-responsive human breast cancer cell populations in vitro. Breast Cancer: Targets and Therapy 9 347-357. (https://doi. org/10.2147/BCTT.S135371)

Graham JD, Yeates C, Balleine RL, Harvey SS, Milliken JS, Bilous AM \& Clarke CL 1995 Characterization of progesterone receptor A and B expression in human breast cancer. Cancer Research 55 5063-5068.

Greendale G 1998 Symptom relief and side effects of postmenopausal hormones: results from the postmenopausal estrogen/progestin interventions trial. Obstetrics and Gynecology 92 982-988. (https:// doi.org/10.1016/S0029-7844(98)00305-6)

Greendale GA, Lee NP \& Arriola ER 1999 The menopause. Lancet 353 571-580. (https://doi.org/10.1016/S0140-6736(98)05352-5)

Greenspan SL, Resnick NM \& Parker RA 2005 The effect of hormone replacement on physical performance in community-dwelling elderly women. American Journal of Medicine 118 1232-1239. (https://doi.org/10.1016/j.amjmed.2005.03.004)

Greeve MA, Allan RK, Harvey JM \& Bentel JM 2004 Inhibition of MCF-7 breast cancer cell proliferation by $5 \alpha$-dihydrotestosterone, a role for p21 Cip1/Waf1. Journal of Molecular Endocrinology 32 793-810. (https:// doi.org/10.1677/jme.0.0320793)

Griekspoor A, Zwart W, Neefjes J \& Michalides R 2007 Visualizing the action of steroid hormone receptors in living cells. Nuclear Receptor Signaling 4 e003. (https://doi.org/10.1621/nrs.05003)

Grimm SL, Hartig SM \& Edwards DP 2016 Progesterone receptor signaling mechanisms. Journal of Molecular Biology 428 3831-3849. (https://doi.org/10.1016/j.jmb.2016.06.020)

Groshong S, Owen G, Grimison B, Schauer I, Todd M, Langan T, Sclafani R, Lange C \& Horwitz K 1997 Biphasic regulation of breast cancer cell growth by progesterone: role of the cyclin-dependent kinase inhibitors, p21 and p27Kip1. Molecular Endocrinology 11 1593-1607. (https://doi.org/10.1210/mend.11.11.0006)

Guidozzi F, Alperstein A, Bagratee JS, Dalmeyer P, Davey M, Villiers TJ De, Hirschowitz S, Kopenhager T, Moodley SP, Roos P, et al. 2014 South African Menopause Society revised consensus position statement on menopausal hormone therapy, 2014. South African Medical Journal 104 537-543. (https://doi.org/10.7196/samj.8423)

Gutendorf B \& Westendorf J 2001 Comparison of an array of in vitro assays for the assessment of the estrogenic potential of natural and synthetic estrogens, phytoestrogens and xenoestrogens. Toxicology 166 79-89. (https://doi.org/10.1016/S0300-483X(01)00437-1)

Hackenberg R, Lüttchens S, Hofmann J, Kunzmann R, Hölzel F \& Schulz KD 1991 Androgen sensitivity of the new human breast cancer cell line MFM-223. Cancer Research 51 5722-5727.

Hammes SR \& Levin ER 2007 Extranuclear steroid receptors: nature and actions. Endocrine Reviews 28 726-741. (https://doi.org/10.1210/ er.2007-0022)

Hammond GL, Lähteenmäki PLA, Lähteenmäki P \& Luukkainen T 1982 Distribution and percentages of non-protein bound contraceptive steroids in human serum. Journal of Steroid Biochemistry 17 375-380. (https://doi:10.1016/0022-4731(82)90629-X)

Hapgood JP, Koubovec D, Louw A \& Africander D 2004 Not all progestins are the same: implications for usage. Trends in Pharmacological Sciences 25 554-557. (https://doi.org/10.1016/j. tips.2004.09.005) 
Hapgood JP, Africander D, Louw R, Ray RM \& Rohwer JM 2014 Potency of progestogens used in hormonal therapy: toward understanding differential actions. Journal of Steroid Biochemistry and Molecular Biology 142 39-47. (https://doi.org/10.1016/j.jsbmb.2013.08.001)

Harnish DC, Scicchitano MS, Adelman SJ, Lyttle CR \& Karathanasis SK 2000 The role of CBP in estrogen receptor cross-talk with nuclear factor-кB in HepG2 cells. Endocrinology 141 3403-3411. (https://doi. org/10.1210/en.141.9.3403)

Hayashi T, Kano H, Sumi D, Iguchi A, Ito I \& Endo H 2002 The longterm effect of estriol on endothelial function and bone mineral density in octogenarian women. Journal of the American Geriatrics Society $\mathbf{5 0} 777-778$. (https://doi. org/10.1046/j.1532-5415.2002.50182.x)

Heldring N, Pike A, Andersson S, Matthews J, Cheng G, Hartman J, Tujague M, Strom A, Treuter E, Warner M, et al. 2007 Estrogen receptors: how do they signal and what are their targets. Physiological Reviews 87 905-931. (https://doi.org/10.1152/ physrev.00026.2006)

Herrington DM, Reboussin DM, Brosnihan KB, Sharp PC, Shumaker SA, Snyder TE, Furberg CD, Kowalchuk GJ, Stuckey TD, Rogers WJ, et al. 2000 Effects of estrogen replacement on the progression of coronaryartery atherosclerosis. New England Journal of Medicine 343 522-529. (https://doi.org/10.1056/NEJM200008243430801)

Hickey TE, Robinson JLL, Carroll JS \& Tilley WD 2012 Minireview: the androgen receptor in breast tissues: growth inhibitor, tumor suppressor, oncogene? Molecular Endocrinology 26 1252-1267. (https://doi.org/10.1210/me.2012-1107)

Hissom JR \& Moore MR 1987 Progestin effects on growth in the human breast cancer cell line T-47D-possible therapeutic implications. Biochemical and Biophysical Research Communications 145 706-711. (https://doi.org/10.1016/0006-291X(87)91022-9)

Hodis HN, Mack WJ, Henderson VW, Shoupe D, Budoff MJ, HwangLevine J, Li Y, Feng M, Dustin L, Kono N, et al. 2016 Vascular effects of early versus late postmenopausal treatment with estradiol. New England Journal of Medicine 374 1221-1231. (https://doi.org/10.1056/ NEJMoa1505241)

Holtorf K 2009 The bioidentical hormone debate: are bioidentical hormones (estradiol, estriol, and progesterone) safer or more efficacious than commonly used synthetic versions in hormone replacement therapy? Postgraduate Medicine 121 73-85. (https://doi. org/10.3810/pgm.2009.01.1949)

Honma N, Horii R, Iwase T, Saji S, Younes M, Takubo K, Matsuura M, Ito Y, Akiyama F \& Sakamoto G 2008 Clinical importance of estrogen receptor- $\beta$ evaluation in breast cancer patients treated with adjuvant tamoxifen therapy. Journal of Clinical Oncology $\mathbf{2 6}$ 3727-3734. (https://doi.org/10.1200/JCO.2007.14.2968)

Horwitz KB \& Freidenberg GR 1985 Growth inhibition and increase of insulin receptors in antiestrogen-resistant $\mathrm{T}_{4} 7 \mathrm{D}_{\mathrm{CO}}$ human breast cancer cells by progestins: implications for endocrine therapies. Cancer Research 45 167-173.

Horwitz KB \& McGuire WL 1975 Predicting response to endocrine therapy in human breast cancer: a hypothesis. Science 189 726-727.

Horwitz KB \& Sartorius CA 2008 Progestins in hormone replacement therapies reactivate cancer stem cells in women with preexisting breast cancers: a hypothesis. Journal of Clinical Endocrinology and Metabolism 93 3295-3298. (https://doi.org/10.1210/jc.2008-0938)

Horwitz KB, Zava DT, Thilagar AK, Jensen EM \& McGuire WL 1978 Steroid receptor analyses of nine human breast cancer cell lines. Cancer Research 38 2434-2437.

Hudson T 1996 Women's health update: wild yam, natural progesterone, unraveling the confusion. Townsend Letter for Doctors and Patients $\mathbf{3}$ $125-128$.

Hulley S, Grady D, Bush T, Furberg C, Herrington D, Riggs B \& Vittinghoff E 1998 Randomized trial of estrogen plus progestin for secondary prevention of coronary heart disease in postmenopausa women. Heart and Estrogen/Progestin Replacement Study (HERS)
Research Group. JAMA 280 605-613. (https://doi.org/10.1001/ jama.280.7.605)

Hulley S, Furberg C, Barrett-Connor E, Cauley J, Grady D, Haskell W, Knopp R, Lowery M, Satterfield S, Schrott H, et al. 2002 Noncardiovascular disease outcomes during 6.8 years of hormone therapy. JAMA 288 58-66. (https://doi.org/10.1001/jama.288.1.58)

Hyder SM, Chiappetta C \& Stancel GM 2001 Pharmacological and endogenous progestins induce vascular endothelial growth factor expression in human breast cancer cells. International Journal of Cancer 92 469-473. (https://doi.org/10.1002/ijc.1236)

Itoi H, Minakami H \& Sato I 1997 Comparison of the long-term effects of oral estriol with the effects of conjugated estrogen, 1-alphahydroxyvitamin D3 and calcium lactate on vertebral bone loss in early menopausal women. Maturitas 28 11-17.

Jacobsen BM, Richer JK, Schittone SA \& Horwitz KB 2002 New human breast cancer cells to study progesterone receptor isoform ratio effects and ligand-independent gene regulation. Journal of Biological Chemistry 277 27793-27800. (https://doi.org/10.1074/jbc. M202584200)

Jiang Q-F, Wu T-T, Yang J-Y, Dong C-R, Wang N, Liu X-H \& Liu Z-M $201317 \beta$-Estradiol promotes the invasion and migration of nuclear estrogen receptor-negative breast cancer cells through cross-talk between GPER1 and CXCR1. Journal of Steroid Biochemistry and Molecular Biology 138 314-324. (https://doi.org/10.1016/j. jsbmb.2013.07.011)

Johnson SR 1998 Menopause and hormone replacement therapy. Medical Clinics of North America 82 297-320. (https://doi. org/10.1177/1755738015571771)

Kagan R, Williams RS, Pan K, Mirkin S \& Pickar JH 2010 A randomized, placebo- and active-controlled trial of bazedoxifene/conjugated estrogens for treatment of moderate to severe vulvar/vaginal atrophy in postmenopausal women. Menopause 17 281-289. (https://doi. org/10.1097/gme.0b013e3181b7c65f)

Kamenov Z, Kolarov G, Orbetzova M, Aoki N, Imamura M, Higashino H, Protich M \& Nalbanski B 2000 Low dose estradiol valerate plus estriol can preserve bone loss in the forearm and attenuate climacteric symptoms in early postmenopausal women. Archives of Hellenic Medicine 17 600-608.

Kampa M, Nifli A-P, Charalampopoulos I, Alexaki V-I, Theodoropoulos PA, Stathopoulos EN, Gravanis A \& Castanas E 2005 Opposing effects of estradiol- and testosterone-membrane binding sites on T47D breast cancer cell apoptosis. Experimental Cell Research 307 41-51. (https://doi.org/10.1016/j.yexcr.2005.02.027)

Karmakar S, Jin Y \& Nagaich AK 2013 Interaction of glucocorticoid receptor (GR) with estrogen receptor $(\mathrm{ER}) \alpha$ and activator protein 1 (AP1) in dexamethasone-mediated interference of ER $\alpha$ Activity. Journal of Biological Chemistry 288 24020-24034. (https://doi. org/10.1074/jbc.M113.473819)

Kastner P, Krust A, Turcotte B, Stropp U, Tora L, Gronemeyer H \& Chambon P 1990 Two distinct estrogen-regulated promoters generate transcripts encoding the two functionally different human progesterone receptor forms A and B. EMBO Journal 9 1603-1614.

Kato S, Pinto M, Carvajal A, Espinoza N, Monso C, Sadarangani A, Villalon M, Brosens JJ, White JO, Richer JK, et al. 2005 Progesterone increases tissue factor gene expression, procoagulant activity, and invasion in the breast cancer cell line ZR-75-1. Journal of Clinical Endocrinology and Metabolism 90 1181-1188. (https://doi. org/10.1210/jc.2004-0857)

Kemppainen JA, Langley E, Wong C, Bobseine K, Kelce WR \& Wilson EM 1999 Distinguishing androgen receptor agonists and antagonists: distinct mechanisms of activation by medroxyprogesterone acetate and dihydrotestosterone. Molecular Endocrinology 13 440-454. (https://doi.org/10.1210/mend.13.3.0255)

Kharode Y, Bodine PVN, Miller CP, Lyttle CR \& Komm BS 2008 The pairing of a selective estrogen receptor modulator, Bazedoxifene, with conjugated estrogens as a new paradigm for the treatment of 
menopausal symptoms and osteoporosis prevention. Endocrinology 149 6084-6091. (https://doi.org/10.1210/en.2008-0817)

Kian Tee M, Rogatsky I, Tzagarakis-foster C, Cvoro A, An J, Christy RJ, Yamamoto KR \& Leitman DC 2003 Estradiol and selective estrogen receptor modulators differentially regulate target genes with estrogen receptors $\alpha$ and $\beta$. Molecular Biology of the Cell 15 1262-1272. (https://doi.org/10.1091/mbc.E03-06-0360)

Kingsley-Kallesen M, Mukhopadhyay SS, Wyszomierski SL, Schanler S, Schütz G \& Rosen JM 2002 The mineralocorticoid receptor may compensate for the loss of the glucocorticoid receptor at specific stages of mammary gland development. Molecular Endocrinology 16 2008-2018. (https://doi.org/10.1210/me.2002-0103)

Komm BS \& Chines AA 2012 Bazedoxifene: the evolving role of thirdgeneration selective estrogen-receptor modulators in the management of postmenopausal osteoporosis. Therapeutic Advances in Musculoskeletal Disease 4 21-34. (https://doi.org/10.1177/17597 20X11422602)

Koubovec D, Ronacher K, Stubsrud E, Louw A \& Hapgood JP 2005 Synthetic progestins used in HRT have different glucocorticoid agonist properties. Molecular and Cellular Endocrinology 242 23-32. (https://doi.org/10.1016/j.mce.2005.07.001)

Kraus WL, Weis KE \& Katzenellenbogen BS 1995 Inhibitory cross-talk between steroid hormone receptors: differential targeting of estrogen receptor in the repression of its transcriptional activity by agonistand antagonist-occupied progestin receptors. Molecular and Cellular Biology 15 1847-1857. (https://doi.org/10.1128/MCB.15.4.1847)

Kraus WL, Weis KE \& Katzenellenbogen BS 1997 Determinants for the repression of estrogen receptor transcriptional activity by ligandoccupied progestin receptors. Journal of Steroid Biochemistry and Molecular Biology 63 175-188. (https://doi.org/10.1016/S0960-0760(97)00089-7)

Krieger N, Löwy I, Aronowitz R, Bigby J, Dickersin K, Garner E, Gaudillière J-P, Hinestrosa C, Hubbard R, Johnson PA, et al. 2005 Hormone replacement therapy, cancer, controversies, and women's health: historical, epidemiological, biological, clinical, and advocacy perspectives. Journal of Epidemiology and Community Health 59 740-748. (https://doi.org/10.1136/jech.2005.033316)

Krug AW, Pojoga LH, Williams GH \& Adler GK 2011 Cell membraneassociated mineralocorticoid receptors? New evidence. Hypertension 57 1019-1025. (https://doi.org/10.1161/ HYPERTENSIONAHA.110.159459)

Kuhl H 1990 Pharmacokinetics of oestrogens and progestogens. Maturitas 12 171-197. (https://doi:10.1016/0378-5122(90)90003-O)

Kuhl H 2005 Pharmacology of estrogens and progestogens: influence of different routes of administration. Climacteric 8 3-63. (https://doi. org/10.1080/13697130500148875)

Kuhnz W, Pfeffer M \& Al-Yacoub G 1990 Protein binding of the contraceptive steroids gestodene, 3-keto-desogestrel and ethinylestradiol in human serum. Journal of Steroid Biochemistry $\mathbf{3 5}$ 313-318. (https://doi.org/10.1016/0002-9378(90)90551-H)

Kuhnz W, Al-Yacoub G \& Fuhrmeister A 1992 Pharmacokinetics of levonorgestrel and ethinylestradiol in 9 women who received a lowdose oral contraceptive over a treatment period of 3 months and, after a wash-out phase, a single oral administration of the same contraceptive formulation. Contraception 46 455-469. (https:// doi:10.1016/0010-7824(92)90149-N)

Kuhnz W, Blode H \& Mahler M 1994 Systemic availability of levonorgestrel after single oral administration of a norgestimate-containing combination oral contraceptive to 12 young women. Contraception 49 255-263. (https://doi:10.1016/0010-7824(94)90043-4)

Kuiper GGJM \& Gustafsson J- $\AA 1997$ The novel estrogen receptor- $\beta$ subtype: potential role in the cell- and promoter-specific actions of estrogens and anti-estrogens. FEBS Letters 410 87-90. (https://doi. org/10.1016/S0014-5793(97)00413-4)

Kuiper GGJM, Enmark E, Pelto-Huikko M, Nilsson S \& Gustafsson JA 1996 Cloning of a novel receptor expressed in rat prostate and ovary. PNAS 93 5925-5930. (https://doi.org/10.1073/pnas.93.12.5925)
Kumar V, Green S, Stack G, Berry M, Jin J-R \& Chambon P 1987 Functional domains of the human estrogen receptor. Cell $\mathbf{5 1}$ 941-951. (https://doi.org/10.1016/0092-8674(87)90581-2)

Labrie F, Luu-The V, Labrie C, Bélanger A, Simard J, Lin S-X \& Pelletier G 2003 Endocrine and intracrine sources of androgens in women: Inhibition of breast cancer and other roles of androgens and their precursor dehydroepiandrosterone. Endocrine Reviews 24 152-182. (https://doi:10.1210/er.2001-0031)

Lanari C, Wargon V, Rojas P \& Molinolo AA 2012 Antiprogestins in breast cancer treatment: are we ready? Endocrine Related Cancer 19 R35-R50. (https://doi.org/10.1530/ERC-11-0378)

Larrea F, García-Becerra R, Lemus AE, García GA, Pérez-Palacios G, Jackson KJ, Coleman KM, Dace R, Smith CL \& Cooney AJ 2001 A-ring reduced metabolites of 19-nor synthetic progestins as subtype selective agonists for ER $\alpha$. Endocrinology 142 3791-3799. (https://doi. org/10.1210/endo.142.9.8401)

Lattrich C, Stegerer A, Häring J, Schüler S, Ortmann O \& Treeck O 2013 Estrogen receptor $\beta$ agonists affect growth and gene expression of human breast cancer cell lines. Steroids 78 195-202. (https://doi. org/10.1016/j.steroids.2012.10.014)

Lazennec G, Bresson D, Lucas A, Chauveau C \& Vignon F 2001 ER $\beta$ inhibits proliferation and invasion of breast cancer cells. Endocrinology 142 4120-4130. (https://doi.org/10.1210/ endo.142.9.8395)

Leehy KA, Regan Anderson TM, Daniel AR, Lange CA \& Ostrander JH 2016 Modifications to glucocorticoid and progesterone receptors alter cell fate in breast cancer. Journal of Molecular Endocrinology 56 R99-R114. (https://doi.org/10.1530/JME-15-0322)

Lemon HM 1975 Estriol prevention of mammary carcinoma induced by 7,12-dimethylbenzanthracene and procarbazine. Cancer Research $\mathbf{3 5}$ 1341-1353.

Lemon HM 1987 Antimammary carcinogenic activity of 17-alphaethinyl estriol. Cancer 60 2873-2881. (https://doi.org/10.1002/10970142(19871215)60:12<2873::AID-CNCR2820601204>3.0.CO;2-B)

Lemus AE, Enríquez J, Hernández A, Santillán R \& Pérez-Palacios G 2009 Bioconversion of norethisterone, a progesterone receptor agonist into estrogen receptor agonists in osteoblastic cells. Journal of Endocrinology 200 199-206. (https://doi.org/10.1677/JOE-08-0166)

Leo JCL, Guo C, Woon CT, Aw SE \& Lin VCL 2004 Glucocorticoid and mineralocorticoid cross-talk with progesterone receptor to induce focal adhesion and growth inhibition in breast cancer cells. Endocrinology 145 1314-1321. (https://doi.org/10.1210/en.2003-0732)

Leung Y-K, Mak P, Hassan S \& Ho S-M 2006 Estrogen receptor (ER)-beta isoforms: a key to understanding ER-beta signaling. PNAS 103 13162-13167. (https://doi.org/10.1073/pnas.0605676103)

Lewis JG, McGill H, Patton VM \& Elder PA 2002 Caution on the use of saliva measurements to monitor absorption of progesterone from transdermal creams in postmenopausal women. Maturitas 41 1-6. (https://doi.org/10.1016/S0378-5122(01)00250-X)

Leygue E \& Murphy LC 2013 A bi-faceted role of estrogen receptor $\beta$ in breast cancer. Endocrine-Related Cancer 20 R127-R139. (https://doi. org/10.1530/ERC-12-0389)

Li H, Fidler ML \& Lim CS 2005 Effect of initial subcellular localization of progesterone receptor on import kinetics and transcriptional activity. Molecular Pharmaceutics 2 509-518. (https://doi.org/10.1021/ mp0500418)

Liang Y, Besch-Williford C, Brekken RA \& Hyder SM 2007 Progestindependent progression of human breast tumor xenografts: a novel model for evaluating antitumor therapeutics. Cancer Research $\mathbf{6 7}$ 9929-9936. (https://doi.org/10.1158/0008-5472.CAN-07-1103)

Liang Y, Benakanakere I, Besch-Williford C, Hyder RS, Ellersieck MR \& Hyder SM 2010 Synthetic progestins induce growth and metastasis of BT-474 human breast cancer xenografts in nude mice. Menopause 17 1040-1047. (https://doi.org/10.1097/gme.0b013e3181d3dd0c)

Lim CS, Baumann CT, Htun H, Xian W, Irie M, Smith CL \& Hager GL 1999 Differential localization and activity of the A- and B-forms of 
the human progesterone receptor using green fluorescent protein chimeras. Molecular Endocrinology 13 366-375. (https://doi. org/10.1210/mend.13.3.0247)

Lim E, Tarulli G, Portman N, Hickey TE, Tilley WD \& Palmieri C 2016 Pushing estrogen receptor around in breast cancer. Endocrine-Related Cancer 23 T227-T241. (https://doi.org/10.1530/ERC-16-0427)

Lippert C, Seeger H \& Mueck AO 2003 The effect of endogenous estradiol metabolites on the proliferation of human breast cancer cells. Life Sciences 72 877-883. (https://doi.org/10.1016/S00243205(02)02305-6)

Lippman M, Monaco ME \& Bolan G 1977 Effects of estrone, estradiol, and estriol on hormone-responsive human breast cancer in longterm tissue culture. Cancer Research 37 1901-1907.

Liu M-M, Albanese C, Anderson CM, Hilty K, Webb P, Uht RM, Price RH, Pestell RG \& Kushner PJ 2002 Opposing action of estrogen receptors $\alpha$ and $\beta$ on cyclin D1 gene expression. Journal of Biological Chemistry 277 24353-24360. (https://doi.org/10.1074/jbc. M201829200)

Liu S, Ruan X, Schultz S, Neubauer H, Fehm T, Seeger H \& Mueck AO 2015 Oestetrol stimulates proliferation and oestrogen receptor expression in breast cancer cell lines: comparison of four oestrogens. European Journal of Contraception and Reproductive Health Care 20 29-35. (https://doi.org/10.3109/13625187.2014.951997)

Lommen E \& Mead JH 2013 Estriol; the 'good' estrogen advances and updates in its clinical uses. Journal of Restorative Medicine 2 45-52. (https://doi.org/10.14200/jrm.2013.2.0103)

Louw-du Toit R, Perkins MS, Hapgood JP \& Africander D 2017 Comparing the androgenic and estrogenic properties of progestins used in contraception and hormone therapy. Biochemical and Biophysical Research Communications 491 140-146. (https://doi. org/10.1016/j.bbrc.2017.07.063)

Luo A, Su D, Zhang X, Qi L, Fu L \& Dong J-T 2016 Estrogen-estrogen receptor signaling suppresses the transcription of ERRF in breast cancer cells. Journal of Genetics and Genomics 43 565-567. (https:// doi.org/10.1016/j.jgg.2016.06.003)

Mangelsdorf DJ, Thummel C, Beato M, Herrlich P, Schutz G, Umesono K, Blumberg B, Kastner P, Mark M, Chambon P, et al. 1995 The nuclear receptor superfamily: the second decade. Cell $\mathbf{8 3}$ 835-839. (https://doi.org/10.1016/0092-8674(95)90199-X)

Manson JE, Chlebowski RT, Stefanick ML, Aragaki AK, Rossouw JE, Prentice RL, Anderson G, Howard B V., Thomson CA, LaCroix AZ, et al. 2013 Menopausal hormone therapy and health outcomes during the intervention and extended poststopping phases of the Women's Health Initiative randomized trials. JAMA 310 1353-1368. (https://doi.org/10.1001/jama.2013.278040)

Marjoribanks J, Farquhar C, Roberts H, Lethaby A \& Lee J 2017 Longterm hormone therapy for perimenopausal and postmenopausal women. Cochrane Database of Systematic Reviews 1 CD004143. (https://doi.org/10.1002/14651858.CD004143.pub5)

Markopoulos C, Berger U, Wilson P, Gazet JC \& Coombes RC 1988 Oestrogen receptor content of normal breast cells and breast carcinomas throughout the menstrual cycle. British Medical Journal (Clinical Research Ed.) 296 1349-1351.

Marsden J 2003 The menopause, hormone replacement therapy and breast cancer. Journal of Steroid Biochemistry and Molecular Biology $\mathbf{8 3}$ 123-132. (https://doi.org/10.1016/S0960-0760(02)00258-3)

Martin P, Cotard M, Mialot J-P, Andre F \& Raynaud J-P 1984 Animal models for hormone-dependent human breast cancer. Cancer Chemotherapy and Pharmacology 12 13-17. (https://doi.org/10.1007/ BF00255902)

Maruyama K, Endoh H, Sasaki-Iwaoka H, Kanou H, Shimaya E, Hashimoto S, Kato S \& Kawashima H 1998 A novel isoform of rat estrogen receptor beta with 18 amino acid insertion in the ligand binding domain as a putative dominant negative regulator of estrogen action. Biochemical and Biophysical Research Communications 246 142-147. (https://doi.org/10.1006/bbrc.1998.8590)
Mattern J, Büchler MW \& Herr I 2007 Cell cycle arrest by glucocorticoids may protect normal tissue and solid tumors from cancer therapy. Cancer Biology and Therapy 6 1345-1354. (https://doi. org/10.4161/cbt.6.9.4765)

Matthews J \& Gustafsson J-A 2003 Estrogen signaling: a subtle balance between ER alpha and ER beta. Molecular Interventions 3 281-292. (https://doi.org/10.1124/mi.3.5.281)

Matthews J, Wihlén B, Tujague M, Wan J, Ström A \& Gustafsson J-Å 2006 Estrogen receptor (ER) $\beta$ modulates ER $\alpha$-mediated transcriptional activation by altering the recruitment of c-Fos and c-Jun to estrogen-responsive promoters. Molecular Endocrinology 20 534-543. (https://doi.org/10.1210/me.2005-0140)

McDonnell DP \& Goldman ME 1994 RU486 exerts antiestrogenic activities through a novel progesterone receptor A form-mediated mechanism. Journal of Biological Chemistry 269 11945-11949.

McDonnell DP, Shahbaz MM, Vegeto E \& Goldman ME 1994 The human progesterone receptor A-form functions as a transcriptional modulator of mineralocorticoid receptor transcriptional activity. Journal of Steroid Biochemistry and Molecular Biology 48 425-432. (https://doi.org/10.1016/0960-0760(94)90190-2)

McFall T, McKnight B, Rosati R, Kim S, Huang Y, Viola-Villegas N \& Ratnam M 2018 Progesterone receptor A promotes invasiveness and metastasis of luminal breast cancer by suppressing regulation of critical microRNAs by estrogen. Journal of Biological Chemistry 293 1163-1177. (https://doi.org/10.1074/jbc.M117.812438)

McNamara KM, Moore NL, Hickey TE, Sasano H \& Tilley WD 2014 Complexities of androgen receptor signalling in breast cancer. Endocrine-Related Cancer 21 T161-T181. (https://doi.org/10.1530/ ERC-14-0243)

McNamara KM, Guestini F, Sakurai M, Kikuchi K \& Sasano H 2016 How far have we come in terms of estrogens in breast cancer? Endocrine Journal 63 413-424. (https://doi.org/10.1507/endocrj.EJ16-0022)

McNamara KM, Kannai A \& Sasano H 2017 Possible roles for glucocorticoid signalling in breast cancer. Molecular and Cellular Endocrinology 466 38-50. (https://doi.org/10.1016/j.mce.2017.07.004)

McTiernan A, Tworoger SS, Ulrich CM, Yasui Y, Irwin ML, Rajan KB, Sorensen B, Rudolph RE, Bowen D, Stanczyk FZ 2004 Effect of exercise on serum estrogens in postmenopausal women: A 12-month randomized clinical trial. Cancer Research 64 2923-2928. (https:// doi:10.1158/0008-5472.CAN-03-3393)

Melamed M, Castaño E, Notides A \& Sasson S 1997 Molecular and kinetic basis for the mixed agonist/antagonist activity of estriol. Molecular Endocrinology 11 1868-1878. (https://doi.org/10.1210/ mend.11.12.0025)

Migliaccio A, Piccolo D, Castoria G, Di Domenico M, Bilancio A, Lombardi M, Gong W, Beato M \& Auricchio F 1998 Activation of the Src/p21 ras/Erk pathway by progesterone receptor via cross-talk with estrogen receptor. EMBO Journal 17 2008-2018. (https://doi. org/10.1093/emboj/17.7.2008)

Million Women Study Collaborators 2003 Breast cancer and hormonereplacement therapy in the Million Women Study. Lancet 362 419-427. (https://doi.org/10.1016/S0140-6736(03)14065-2)

Minaguchi H, Uemura T, Shirasu K, Sato A, Tsukikawa S, Ibuki Y, Mizunuma H, Aso T, Koyama T, Nozawa S, et al. 1996 Effect of estriol on bone loss in postmenopausal Japanese women: a multicenter prospective open study. Journal of Obstetrics and Gynaecology Research 22 259-265. (https://doi. org/10.1111/j.1447-0756.1996.tb00976.x)

Miranda TB, Voss TC, Sung M-H, Baek S, John S, Hawkins M, Grontved L, Schiltz RL \& Hager GL 2013 Reprogramming the chromatin landscape: interplay of the estrogen and glucocorticoid receptors at the genomic level. Cancer Research 73 5130-5139. (https://doi.org/10.1158/0008-5472.CAN-13-0742)

Mirkin S, Amadio JM, Bernick BA, Pickar JH \& Archer DF 2015 $17 \beta$-Estradiol and natural progesterone for menopausal hormone therapy: REPLENISH phase 3 study design of a combination capsule 
and evidence review. Maturitas 81 28-35. (https://doi.org/10.1016/j. maturitas.2015.02.266)

Mohammed H, Russell IA, Stark R, Rueda OM, Hickey TE, Tarulli GA, Serandour AAA, Birrell SN, Bruna A, Saadi A, et al. 2015 Progesterone receptor modulates ER $\alpha$ action in breast cancer. Nature 523 313-317. (https://doi.org/10.1038/nature14583)

Monroe DG, Getz BJ, Johnsen SA, Riggs BL, Khosla S \& Spelsberg TC 2003 Estrogen receptor isoform-specific regulation of endogenous gene expression in human osteoblastic cell lines expressing either $\mathrm{ER} \alpha$ or ER $\beta$. Journal of Cellular Biochemistry 90 315-326. (https://doi. org $/ 10.1002 / j \mathrm{jcb} .10633)$

Moore MR, Conover JL \& Franks KM 2000 Progestin effects on longterm growth, death, and Bcl-xL in breast cancer cells. Biochemical and Biophysical Research Communications 277 650-654. (https://doi. org/10.1006/bbrc.2000.3728)

Moore MR, Spence JB, Kiningham KK \& Dillon JL 2006 Progestin inhibition of cell death in human breast cancer cell lines. Journal of Steroid Biochemistry and Molecular Biology 98 218-227. (https://doi. org/10.1016/j.jsbmb.2005.09.008)

Mote PA, Balleine RL, McGowan EM \& Clarke CL 1999 Colocalization of progesterone receptors a and $\mathrm{b}$ by dual immunofluorescent histochemistry in human endometrium during the menstrual cycle. Journal of Clinical Endocrinology and Metabolism 84 2963-2971. (https://doi.org/10.1210/jcem.84.8.5928)

Mote PA, Bartow S, Tran N \& Clarke CL 2002 Loss of co-ordinate expression of progesterone receptors A and B is an early event in breast carcinogenesis. Breast Cancer Research and Treatment $\mathbf{7 2}$ 163-172. (https://doi.org/10.1023/A:1014820500738)

Moutsatsou P \& Papavassiliou AG 2007 The glucocorticoid receptor signalling in breast cancer. Journal of Cellular and Molecular Medicine 12 145-163. (https://doi.org/10.1111/j.1582-4934.2007.00177.x)

Mueck AO, Seeger H \& Wallwiener D 2003 Comparison of the proliferative effects of estradiol and conjugated equine estrogens on human breast cancer cells and impact of continuous combined progestogen addition. Climacteric: The Journal of the International Menopause Society 6 221-227. (https://doi.org/10.1080/ cmt.6.3.221.227)

Mueller MD, Vigne JL, Minchenko A, Lebovic DI, Leitman DC \& Taylor RN 2000 Regulation of vascular endothelial growth factor (VEGF) gene transcription by estrogen receptors $\alpha$ and $\beta$. PNAS 97 10972-10977. (https://doi.org/10.1073/pnas.200377097)

Mulac-Jericevic B, Lydon JP, DeMayo FJ \& Conneely OM 2003 Defective mammary gland morphogenesis in mice lacking the progesterone receptor B isoform. PNAS 100 9744-9749. (https://doi.org/10.1073/ pnas.1732707100)

Musgrove EA, Lee CS \& Sutherland RL 1991 Progestins both stimulate and inhibit breast cancer cell cycle progression while increasing expression of transforming growth factor $\alpha$, epidermal growth factor receptor, c-fos, and c-myc genes. Molecular and Cellular Biology 11 5032-5043.

Nachtigall LE, Nachtigall RH, Nachtigall RD \& Beckman EM 1979 Estrogen replacement therapy I: a prospective study in the relationship to carcinoma and cardiovascular and metabolic problems. Obstetrics and Gynecology 54 74-79.

Need EF, Selth LA, Harris TJ, Birrell SN, Tilley WD \& Buchanan G 2012 Research resource: interplay between the genomic and transcriptional networks of androgen receptor and estrogen receptor $\alpha$ in luminal breast cancer cells. Molecular Endocrinology 26 1941-1952. (https://doi.org/10.1210/me.2011-1314)

Nelson AW, Groen AJ, Miller JL, Warren AY, Holmes KA, Tarulli GA, Tilley WD, Katzenellenbogen BS, Hawse JR, Gnanapragasam VJ, et al. 2017 Comprehensive assessment of estrogen receptor beta antibodies in cancer cell line models and tissue reveals critical limitations in reagent specificity. Molecular and Cellular Endocrinology 440 138-150. (https://doi.org/10.1016/j. mce.2016.11.016)
Notelovitz M, John VA \& Good WR 2002 Effectiveness of Alora estradiol matrix transdermal delivery system in improving lumbar bone mineral density in healthy, postmenopausal women. Menopause 9 343-353. (https://doi.org/10.1097/00042192-200209000-00007)

O'leary P, Feddema P, Chan K, Taranto M, Smith M \& Evans S 2000 Salivary, but not serum or urinary levels of progesterone are elevated after topical application of progesterone cream to pre-and postmenopausal women. Clinical Endocrinology 53 615-620. (https:// doi.org/10.1046/j.1365-2265.2000.01130.x)

Obel EB, Munk-Jensen N, Svenstrup B, Bennett P, Micic S, HenrikNielsen R, Pors Nielsen S, Gydesen H \& Jensen BM 1993 A two-year double-blind controlled study of the clinical effect of combined and sequential postmenopausal replacement therapy and steroid metabolism during treatment. Maturitas 16 13-21. (https://doi. org/10.1016/0378-5122(93)90129-6)

Ogawa S, Inoue S, Watanabe T, Orimo A, Hosoi T, Ouchi Y \& Muramatsu M 1998 Molecular cloning and characterization of human estrogen receptor $\beta \mathrm{cx}$ : a potential inhibitor of estrogen action in human. Nucleic Acids Research 26 3505-3512. (https://doi. org/10.1093/nar/26.15.3505)

Ortmann J, Prifti S, Bohlmann MK, Rehberger-Schneider S, Strowitzki T \& Rabe T 2002 Testosterone and $5 \alpha$-dihydrotestosterone inhibit in vitro growth of human breast cancer cell lines. Gynecological Endocrinology 16 113-120. (https://doi.org/10.1080/gye.16.2. 113.120)

Ory K, Lebeau J, Levalois C, Bishay K, Fouchet P, Allemand I, Therwath A \& Chevillard S 2001 Apoptosis inhibition mediated by medroxyprogesterone acetate treatment of breast cancer cell lines. Breast Cancer Research and Treatment 68 187-198. (https://doi. org/10.1023/A:1012288510743)

Pan D, Kocherginsky M \& Conzen SD 2011 Activation of the glucocorticoid receptor is associated with poor prognosis in estrogen receptor-negative breast cancer. Cancer Research 71 6360-6370. (https://doi.org/10.1158/0008-5472.CAN-11-0362)

Pardridge M 1981 Transport of protein-bound hormones into tissues in vivo. Endocrine Reviews 2 103-123. (https://doi.org/10.1210/edrv-2-1103)

Paruthiyil S, Cvoro A, Zhao X, Wu Z, Sui Y, Staub RE, Baggett S, Herber CB, Griffin C, Tagliaferri M, et al. 2009 Drug and cell typespecific regulation of genes with different classes of estrogen receptor $\beta$-selective agonists. PLoS ONE 4 e6271. (https://doi.org/10.1371/ journal.pone.0006271)

Pasapera AM, Gutiérrez-Sagal R, Herrera J, Galicia-Canales N, Garcı冈a de la Mora G \& Ulloa-Aguirre A 2002 Norethisterone is bioconverted to oestrogenic compounds that activate both the oestrogen receptor $\alpha$ and oestrogen receptor $\beta$ in vitro. European Journal of Pharmacology 452 347-355. (https://doi.org/10.1016/S0014-2999(02)02337-3)

Perkins MS, Louw-du Toit R \& Africander D 2017 A comparative characterization of estrogens used in hormone therapy via estrogen receptor (ER)- $\alpha$ and $-\beta$. Journal of Steroid Biochemistry and Molecular Biology 174 27-39. (https://doi.org/10.1016/j.jsbmb.2017.07.022)

Peters AA, Buchanan G, Ricciardelli C, Bianco-Miotto T, Centenera MM, Harris JM, Jindal S, Segara D, Jia L, Moore NL, et al. 2009 Androgen receptor inhibits estrogen receptor- $\alpha$ activity and is prognostic in breast cancer. Cancer Research 69 6131-6140. (https://doi. org/10.1158/0008-5472.CAN-09-0452)

Pettersson K \& Gustafsson J-Å 2001 Role of estrogen receptor beta in estrogen action. Annual Review of Physiology 63 165-192. (https://doi. org/10.1146/annurev.physiol.63.1.165)

Pinkerton JV 2012 The truth about bioidentical hormone therapy. Female Patient 37 16-19.

Pinkerton JV 2014 What are the concerns about custom-compounded 'bioidentical' hormone therapy? Menopause 21 2012-2014. (https:// doi.org/10.1097/GME.0000000000000376)

Pinkerton J V., Utian WH, Constantine GD, Olivier S \& Pickar JH 2009 Relief of vasomotor symptoms with the tissue-selective estrogen 
complex containing bazedoxifene/conjugated estrogens. Menopause 16 1116-1124. (https://doi.org/10.1097/gme.0b013e3181a7df0d)

Platet N, Cathiard AM, Gleizes M \& Garcia M 2004 Estrogens and their receptors in breast cancer progression: a dual role in cancer proliferation and invasion. Critical Reviews in Oncology/Hematology 51 55-67. (https://doi.org/10.1016/j.critrevonc.2004.02.001)

Pratt WB \& Toft DO 1997 Steroid receptor interactions with heat shock protein and immunophilin chaperones. Endocrine Reviews $\mathbf{1 8}$ 306-360. (https://doi.org/10.1210/edrv.18.3.0303)

Preston-Martin S, Pike MC, Ross RK, Jones PA \& Henderson BE 1990 Increased cell division as a cause of human cancer. Cancer Research 50 7415-7421.

Pujol P, Daures J, Thezenas S, Guilleux F, Rouanet P \& Grenier J 1998 Changing estrogen and progesterone receptor patterns in breast carcinoma during the menstrual cycle and menopause. Cancer $\mathbf{8 3}$ 698-705. (https://doi.org/10.1002/(SICI)1097-

0142(19980815)83:4<698::AID-CNCR10>3.0.CO;2-N)

Rahim B \& O'Regan R 2017 AR signaling in breast cancer. Cancers 9 21-47. (https://doi.org/10.3390/cancers9030021)

Ramsey TL, Risinger KE, Jernigan SC, Mattingly KA \& Klinge CM 2004 Estrogen receptor $\beta$ isoforms exhibit differences in ligand-activated transcriptional activity in an estrogen response element sequencedependent manner. Endocrinology 145 149-160. (https://doi. org/10.1210/en.2003-1043)

Reddel RR \& Sutherland RL 1987 Effects of pharmacological concentrations of estrogens on proliferation and cell cycle kinetics of human breast cancer cell lines in vitro. Cancer Research $\mathbf{4 7}$ 5323-5329.

Reed-Kane D 2001 Natural hormone replacement therapy: what it is and what consumers really want. International Journal of Pharmaceutical Compounding 5 332-335.

Richer JK, Jacobsen BM, Manning NG, Abel MG, Wolf DM \& Horwitz KB 2002 Differential gene regulation by the two progesterone receptor isoforms in human breast cancer cells. Journal of Biological Chemistry 277 5209-5218. (https://doi.org/10.1074/jbc.M110090200)

Rigiracciolo DC, Scarpelli A, Lappano R, Pisano A, Santolla MF, Avino S, Marco P De, Bussolati B, Maggiolini M \& De Francesco EM 2016 GPER is involved in the stimulatory effects of aldosterone in breast cancer cells and breast tumor-derived endothelial cells. Oncotarget 7 94-111. (https://doi.org/10.18632/ oncotarget.6475)

Rizza P, Barone I, Zito D, Giordano F, Lanzino M, De Amicis F, Mauro L, Sisci D, Catalano S, Wright KD, et al. 2014 Estrogen receptor beta as a novel target of androgen receptor action in breast cancer cell lines. Breast Cancer Research 16 R21. (https://doi.org/10.1186/bcr3619)

Rothman MS, Carlson NE, Xu M, Wang C, Swerdloff R, Lee P, Goh VHH, Ridgway EC \& Wierman ME 2011 Reexamination of testosterone, dihydrotestosterone, estradiol and estrone levels across the menstrual cycle and in postmenopausal women measured by liquid chromatography-tandem mass spectrometry. Steroids 76 177-182. (https://doi:10.1016/j.steroids.2010.10.010)

Ruohola JK, Valve EM, Karkkainen MJ, Joukov V, Alitalo K \& Härkönen PL 1999 Vascular endothelial growth factors are differentially regulated by steroid hormones and antiestrogens in breast cancer cells. Molecular and Cellular Endocrinology 149 29-40. (https://doi.org/10.1016/S0303-7207(99)00003-9)

Santen R, Cavalieri E, Rogan E, Russo J, Guttenplan J, Ingle J \& Yue W 2009 Estrogen mediation of breast tumor formation involves estrogen receptor-dependent, as well as independent, genotoxic effects. Annals of the New York Academy of Sciences 1155 132-140. (https://doi.org/10.1111/j.1749-6632.2008.03685.x)

Santoro N, Braunstein GD, Butts CL, Martin KA, McDermott M \& Pinkerton JV 2016 Compounded bioidentical hormones in endocrinology practice: an Endocrine Society scientific statement. Journal of Clinical Endocrinology and Metabolism 101 1318-1343. (https://doi.org/10.1210/jc.2016-1271)
Sasano H, Frost AR, Saitoh R, Matsunaga G, Nagura H, Krozowski ZS \& Silverberg SG 1997 Localization of mineralocorticoid receptor and 11 beta-hydroxysteroid dehydrogenase type II in human breast and its disorders. Anticancer Research 17 2001-2007.

Schierbeck LL, Rejnmark L, Tofteng CL, Stilgren L, Eiken P, Mosekilde L, Kober L \& Jensen J-EB 2012 Effect of hormone replacement therapy on cardiovascular events in recently postmenopausal women: randomised trial. BMJ 345 e6409. (https://doi.org/10.1136/bmj.e6409)

Schindler AE, Campagnoli C, Druckmann R, Huber J, Pasqualini JR, Schweppe KW \& Thijssen JH 2003 Classification and pharmacology of progestins. Maturitas 46 7-16. (https://doi.org/10.1016/j. maturitas.2003.09.014)

Schoonen WGEJ, Joosten JWH \& Kloosterboer HJ 1995 Effects of two classes of progestagens, pregnane and 19-nortestosterone derivatives, on cell growth of human breast tumor cells: I. MCF-7 cell lines. Journal of Steroid Biochemistry and Molecular Biology 55 423-437. (https://doi.org/10.1016/0960-0760(95)00215-4)

Schwartz N, Verma A, Bivens CB, Schwartz Z \& Boyan BD 2016 Rapid steroid hormone actions via membrane receptors. Biochimica et Biophysica Acta (BBA): Molecular Cell Research 1863 2289-2298. (https://doi.org/10.1016/j.bbamcr.2016.06.004)

Shang D, Li Z, Zhu Z, Chen H, Zhao L, Wang X \& Chen Y 2015 Baicalein suppresses 17- $\beta$-estradiol-induced migration, adhesion and invasion of breast cancer cells via the $\mathrm{G}$ protein-coupled receptor 30 signaling pathway. Oncology Reports 33 2077-2085. (https://doi. org/10.3892/or.2015.3786)

Siegel RL, Miller KD \& Jemal A2016 Cancer statistics, 2016 CA Cancer J Clin 66 7-30. (https://doi.org/10.3322/caac.21332.)

Sikora MJ 2016 Family matters: collaboration and conflict among the steroid receptors raises a need for group therapy. Endocrinology 157 4553-4560. (https://doi.org/10.1210/en.2016-1778)

Singhal H, Greene ME, Tarulli G, Zarnke AL, Bourgo RJ, Laine M, Chang Y-F, Ma S, Dembo AG, Raj G V, et al. 2016 Genomic agonism and phenotypic antagonism between estrogen and progesterone receptors in breast cancer. Science Advances 2 e1501924-e1501924. (https://doi.org/10.1126/sciadv.1501924)

Sites CK 2008 Bioidentical hormones for menopausal therapy. Women's Health 4 163-171. (https://doi.org/10.2217/17455057.4.2.163)

Sitruk-Ware R 2004 Pharmacological profile of progestins. Maturitas $\mathbf{4 7}$ 277-283. (https://doi.org/10.1016/j.maturitas.2004.01.001)

Sitruk-Ware R \& Nath A 2010 The use of newer progestins for contraception. Contraception 82 410-417. (https://doi.org/10.1016/j. contraception.2010.04.004)

Smith DC, Prentice R, Thompson DJ \& Herrmann WL 1975 Association of exogenous estrogen and endometrial carcinoma. New England Journal of Medicine 293 1164-1167. (https://doi.org/10.1056/ NEJM197512042932302)

Song RX, Mor G, Naftolin F, McPherson RA, Song J, Zhang Z, Yue W, Wang J \& Santen RJ 2001 Effect of long-term estrogen deprivation on apoptotic responses of breast cancer cells to 17beta-estradiol. Journal of the National Cancer Institute 93 1714-1723. (https://doi. org/10.1093/jnci/93.22.1714)

Sood R, Shuster L, Smith R, Vincent A \& Jatoi A 2011 Counseling postmenopausal women about bioidentical hormones: ten discussion points for practicing physicians. Journal of the American Board of Family Medicine 24 202-210. (https://doi.org/10.3122/ jabfm.2011.02.100194)

Sood R, Warndahl RA, Schroeder DR, Singh RJ, Rhodes DJ, WahnerRoedler D, Bahn RS \& Shuster LT 2013 Bioidentical compounded hormones: a pharmacokinetic evaluation in a randomized clinical trial. Maturitas 74 375-382. (https://doi.org/10.1016/j. maturitas.2013.01.010)

Sood R, Faubion SS, Kuhle CL, Thielen JM \& Shuster LT 2014 Prescribing menopausal hormone therapy: An evidence-based approach. International Journal of Women's Health 6 47-57. (https://doi. org/10.2147/IJWH.S38342) 
Soto AM \& Sonnenschein C 1985 The role of estrogens on the proliferation of human breast tumor cells (MCF-7). Journal of Steroid Biochemistry 23 87-94. (https://doi.org/10.1016/0022-4731(85)90265-1)

Stanczyk FZ 2002 Pharmacokinetics and potency of progestins used for hormone replacement therapy and contraception. Reviews in Endocrine and Metabolic Disorders 3 211-224. (https:// doi:10.1023/A:1020072325818)

Stanczyk FZ, Hapgood JP, Winer S \& Mishell DR 2013 Progestogens used in postmenopausal hormone therapy: differences in their pharmacological properties, intracellular actions, and clinical effects. Endocrine Reviews 34 171-208. (https://doi.org/10.1210/er.2012)

Stefanick ML 2005 Estrogens and progestins: background and history, trends in use, and guidelines and regimens approved by the US Food and Drug Administration. American Journal of Medicine 118 64-73. (https://doi.org/10.1016/j.amjmed.2005.09.059)

Stefanick ML, Anderson GL, Margolis KL, Hendrix SL, Rodabough RJ, Paskett ED, Lane DS, Hubbell FA, Assaf AR, Sarto GE, et al. 2006 Effects of conjugated equine estrogens on breast cancer and mammography screening in postmenopausal women with hysterectomy. JAMA 295 1647-1657. (https://doi.org/10.1001/ jama.295.14.1647)

Stossi F, Barnett DH, Frasor J, Komm B, Lyttle CR \& Katzenellenbogen BS 2004 Transcriptional profiling of estrogen-regulated gene expression via estrogen receptor (ER) $\alpha$ or ER $\beta$ in human osteosarcoma cells: distinct and common target genes for these receptors. Endocrinology 145 3473-3486. (https://doi.org/10.1210/en.2003-1682)

Strom A, Hartman J, Foster JS, Kietz S, Wimalasena J \& Gustafsson J-Å 2004 Estrogen receptor $\beta$ inhibits $17 \beta$-estradiol-stimulated proliferation of the breast cancer cell line T47D. PNAS 101 1566-1571. (https://doi.org/10.1073/pnas.0308319100)

Stuenkel CA, Davis SR, Gompel A, Lumsden MA, Murad MH, Pinkerton JV \& Santen RJ 2015 Treatment of symptoms of the menopause: an Endocrine Society clinical practice guideline. Journal of Clinical Endocrinology and Metabolism 100 3975-4011. (https://doi. org/10.1210/jc.2015-2236)

Takahashi K, Manabe A, Okada M, Kurioka H, Kanasaki H \& Miyazaki K 2000 Efficacy and safety of oral estriol for managing postmenopausal symptoms. Maturitas 34 169-177. (https://doi.org/10.1016/S03785122(99)00108-5)

Tarulli GA, Butler LM, Tilley WD \& Hickey TE 2014 Bringing androgens up a NOTCH in breast cancer. Endocrine Related Cancer 21 T183-T202. (https://doi.org/10.1530/ERC-14-0248)

Taylor M 2005 'Bioidentical' estrogens: hope or hype? Sexuality, Reproduction and Menopause 3 68-71. (https://doi.org/10.1016/j. sram.2005.09.003)

Tchafa AM, Zhong Z, Meng R, Quong JN \& Quong AA 2013 Increased cellular invasion and proliferation via estrogen receptor after 17 - $\beta$-estradiol treatment in breast cancer cells using stable isotopic labeling with amino acids in cell culture (SILAC). Advances in Breast Cancer Research 2 32-43. (https://doi.org/10.4236/abcr.2013.22007)

The North American Menopause Society (NAMS) 2012 Hormone Therapy Position Statement Advisory Panel 2012 The 2012 hormone therapy position statement of the North American Menopause Society. Menopause: The Journal of the North American Menopause Society 19 257-271. (https://doi.org/10.1097/gme.0b013e31824b970a)

The North American Menopause Society (NAMS) 2012 Hormone Therapy Position Statement Advisory Panel 2017 The 2017 hormone therapy position statement of the North American Menopause Society. Menopause 24 728-753. (https://doi.org/10.1097/ GME.0000000000000921)

The Writing Group for the PEPI Trial 1995 Effects of estrogen or estrogen/ progestin regimens on heart disease risk factors in postmenopausal women. JAMA 273 199-208. (https://doi.org/10.1001/jama.1995. 03520270033028)

Thompson EW, Reich R, Shima TB, Albini A, Graf J, Martin GR, Dickson RB \& Lippman ME 1988 Differential regulation of growth and invasiveness of MCF-7 breast cancer cells by antiestrogens. Cancer Research $\mathbf{4 8}$ 6764-6768.

Tierney MC, Oh P, Moineddin R, Greenblatt EM, Snow WG, Fisher RH, Iazzetta J, Hyslop PSG \& MacLusky NJ 2009 A randomized doubleblind trial of the effects of hormone therapy on delayed verbal recall in older women. Psychoneuroendocrinology 34 1065-1074. (https://doi. org/10.1016/j.psyneuen.2009.02.009)

Torre LA, Bray F, Siegel RL, Ferlay J, Lortet-tieulent J \& Jemal A 2015 Global cancer statistics, 2012. CA: A Cancer Journal of Clinicians. 65 87-108. (https://doi.org/10.3322/caac.21262.)

Treeck O, Juhasz-Boess I, Lattrich C, Horn F, Goerse R \& Ortmann O 2008 Effects of exon-deleted estrogen receptor beta transcript variants on growth, apoptosis and gene expression of human breast cancer cell lines. Breast Cancer Research and Treatment 110 507-520. (https://doi.org/10.1007/s10549-007-9749-7)

Treeck O, Lattrich C, Springwald A \& Ortmann O 2010 Estrogen receptor beta exerts growth-inhibitory effects on human mammary epithelial cells. Breast Cancer Research and Treatment 120 557-565. (https://doi.org/10.1007/s10549-009-0413-2)

van den Brûle FA, Engel J, Stetler-Stevenson WG, Liu F-T, Sobel ME \& Castronovo V 1992 Genes involved in tumor invasion and metastasis are differentially modulated by estradiol and progestin in human breast-cancer cells. International Journal of Cancer 52 653-657. (https://doi.org/10.1002/ijc.2910520426)

Vashisht A, Wadsworth F, Carey A, Carey B \& Studd J 2005 A study to look at hormonal absorption of progesterone cream used in conjunction with transdermal estrogen. Gynecological Endocrinology 21 101-105. (https://doi.org/10.1080/09513590500128583)

Veerus P, Hovi S-L, Fischer K, Rahu M, Hakama M \& Hemminki E 2006 Results from the Estonian postmenopausal hormone therapy trial [ISRCTN35338757]. Maturitas 55 162-173. (https://doi.org/10.1016/j. maturitas.2006.01.012)

Vegeto E, Shahbaz MM, Wen DX, Goldman ME, O'Malley BW \& McDonnell DP 1993 Human progesterone receptor A form is a celland promoter-specific repressor of human progesterone receptor B function. Molecular Endocrinology 7 1244-1255. (https://doi. org/10.1210/mend.7.10.8264658)

Vernocchi S, Battello N, Schmitz S, Revets D, Billing AM, Turner JD \& Muller CP 2013 Membrane glucocorticoid receptor activation induces proteomic changes aligning with classical glucocorticoid effects. Molecular and Cellular Proteomics 12 1764-1779. (https://doi. org/10.1074/mcp.M112.022947)

Vickers MR, Martin J \& Meade TW 2007 The Women's international study of long-duration oestrogen after menopause (WISDOM): a randomised controlled trial. BMC Women's Health 7 2-18. (https:// doi.org/10.1186/1472-6874-7-2)

Vilasco M, Communal L, Mourra N, Courtin A, Forgez P \& Gompel A 2011 Glucocorticoid receptor and breast cancer. Breast Cancer Research and Treatment 130 1-10. (https://doi.org/10.1007/s10549-011-1689-6)

Voss TC, Schiltz RL, Sung MH, Yen PM, Stamatoyannopoulos JA, Biddie SC, Johnson TA, Miranda TB, John S \& Hager GL 2011 Dynamic exchange at regulatory elements during chromatin remodeling underlies assisted loading mechanism. Cell 146 544-554. (https://doi.org/10.1016/j.cell.2011.07.006)

Walker G, MacLeod K, Williams ARW, Cameron DA, Smyth JF \& Langdon SP 2007 Insulin-like growth factor binding proteins IGFBP3, IGFBP4, and IGFBP5 predict endocrine responsiveness in patients with ovarian cancer. Clinical Cancer Research 13 1438-1444. (https://doi.org/10.1158/1078-0432.CCR-06-2245)

Wang TT \& Phang JM 1995 Effects of estrogen on apoptotic pathways in human breast cancer cell line MCF-7. Cancer Research 55 2487-2489.

Wang Z, Zhang X, Shen P, Loggie BW, Chang Y \& Deuel TF 2005 Identification, cloning, and expression of human estrogen receptor- $\alpha 36$, a novel variant of human estrogen receptor- $\alpha 66$. Biochemical and Biophysical Research Communications 336 1023-1027. (https://doi.org/10.1016/j.bbrc.2005.08.226) 
Wargon V, Riggio M, Giulianelli S, Sequeira GR, Rojas P, May M, Polo ML, Gorostiaga MA, Jacobsen B, Molinolo A, et al. 2015 Progestin and antiprogestin responsiveness in breast cancer is driven by the PRA/PRB ratio via AIB1 or SMRT recruitment to the CCND1 and MYC promoters. International Journal of Cancer 136 2680-2692. (https://doi.org/10.1002/ijc.29304)

Warner M, Huang B \& Gustafsson J-A 2017 Estrogen receptor $\beta$ as a pharmaceutical target. Trends in Pharmacological Sciences 38 92-99. (https://doi.org/10.1016/j.tips.2016.10.006)

Waters DD, Alderman EL, Hsia J, Howard BV, Cobb FR, Rogers WJ, Ouyang P, Thompson P, Tardif JC, Higginson L, et al. 2002 Effects of hormone replacement therapy and antioxidant vitamin supplements on coronary atherosclerosis in postmenopausal women. JAMA 288 2432-2440. (https://doi.org/10.1001/jama.288.19.2432)

Watson CS, Jeng Y-J \& Kochukov MY 2008 Nongenomic actions of estradiol compared with estrone and estriol in pituitary tumor cell signaling and proliferation. FASEB Journal 22 3328-3336. (https:// doi.org/10.1096/fj.08-107672)

Weiss NS, Szekely DR \& Austin DF 1976 Increasing incidence of endometrial cancer in the United States. New England Journal of Medicine 294 1259-1262. (https://doi.org/10.1056/ NEJM197606032942303)

Welboren W-J, van Driel MA, Janssen-Megens EM, van Heeringen SJ, Sweep FC, Span PN \& Stunnenberg HG 2009 ChIP-Seq of ER $\alpha$ and RNA polymerase II defines genes differentially responding to ligands. EMBO Journal 28 1418-1428. (https://doi.org/10.1038/ emboj.2009.88)

Werner HMJ, Franke HR \& Vermes I 2005 Apoptosis and proliferation in breast cancer cells, cultured in vitro: effects of SERMs. Climacteric $\mathbf{8}$ 294-299. (https://doi.org/10.1080/13697130500197526)

West DC, Pan D, Tonsing-Carter EY, Hernandez KM, Pierce CF, Styke SC, Bowie KR, Garcia TI, Kocherginsky M \& Conzen SD 2016 GR and ER coactivation alters the expression of differentiation genes and associates with improved ER+ breast cancer outcome. Molecular Cancer Research 14 707-719. (https://doi.org/10.1158/1541-7786. MCR-15-0433)

Wood CE, Clarkson TB, Chen H, Veenstra TD, Xu X, Scott L \& Cline JM 2008 Comparative effects of oral conjugated equine estrogens and micronized 17A-estradiol on breast proliferation: a retrospective analysis. Society 15 890-898. (https://doi.org/10.1097/01. gme.0b013e318168f0ad)

Wren B 2003 Progesterone creams: do they work? Climacteric 6 184-187. (https://doi.org/10.1080/cmt.6.3.184.187)

Wren BG, McFarland K \& Edwards L 1999 Micronised transdermal progesterone and endometrial response. Lancet 354 1447-1448. (https://doi.org/10.1016/S0140-6736(99)03430-3)

Wren BG, Champion SM, Willetts K, Manga RZ \& Eden JA 2003 Transdermal progesterone and its effect on vasomotor symptoms, blood lipid levels, bone metabolic markers, moods, and quality of life for postmenopausal women. Menopause 10 13-18. (https://doi. org/10.1097/01.GME.0000025416.53837.00)

Wright J V. 2005 Bio-identical steroid hormone replacement: Selected observations from 23 years of clinical and laboratory practice. Annals of the New York Academy of Sciences 1057 506-524. (https://doi. org/10.1196/annals.1356.039)

Writing Group for the Women's Health Initiative Investigators 2002 Risks and benefits of estrogen plus progestin in healthy postmenopausal women: principal results from the Women's Health Initiative randomized controlled trial. JAMA 288 321-333. (https:// doi.org/10.1001/jama.288.3.321)

Xie D, Dahl-Smith J, DuBose J, Pepitone C \& Owensby S 2014 Counseling patients about hormone therapy and alternatives for menopausal symptoms. Osteopathic Family Physician 6 15-21.

Yaffe K, Vittinghoff E, Ensrud KE, Johnson KC, Diem S, Hanes V \& Grady D 2006 Effects of ultra-low-dose transdermal estradiol on cognition and health-related quality of life. Archives of Neurology 63 945-950. (https://doi.org/10.1001/archneur.63.7.945)

Yager JD \& Davidson NE 2006 Estrogen carcinogenesis in breast cancer. New England Journal of Medicine 354 270-282. (https://doi. org/10.1056/NEJMra050776)

Yang J \& Young MJ 2009 The mineralocorticoid receptor and its coregulators. Journal of Molecular Endocrinology 43 53-64. (https://doi. org/10.1677/JME-09-0031)

Yang TS, Tsan SH, Chang SP \& Ng HT 1995 Efficacy and safety of estriol replacement therapy for climacteric women. Chinese Medical Journal 55 386-391.

Yang X, Guo Z, Sun F, Li W, Alfano A, Shimelis H, Chen M, Brodie AMH, Chen H, Xiao Z, et al. 2011 Novel membraneassociated androgen receptor splice variant potentiates proliferative and survival responses in prostate cancer cells. Journal of Biological Chemistry 286 36152-36160. (https://doi.org/10.1074/jbc. M111.265124)

Yen S, Strauss JF \& Barbieri RL 2015 Yen and Jaffe's Reproductive Endocrinology. Physiology, Pathophysiology, and Clinical Management. Philadelphia: Saunders, Elsevier. (https://doi.org/10.1111/ aogs.12616)

Yue W, Yager JD, Wang J-P, Jupe ER \& Santen RJ 2013 Estrogen receptordependent and independent mechanisms of breast cancer carcinogenesis. Steroids 78 161-170. (https://doi.org/10.1016/j. steroids.2012.11.001)

Zhang Y, Leung DYM, Nordeen SK \& Goleva E 2009 Estrogen inhibits glucocorticoid action via protein phosphatase 5 (PP5)-mediated glucocorticoid receptor dephosphorylation. Journal of Biological Chemistry 284 24542-24552. (https://doi.org/10.1074/jbc. M109.021469)

Zhao C, Dahlman-Wright K \& Gustafsson J-Å 2008 Estrogen receptor $\beta$ : an overview and update. Nuclear Receptor Signaling 6 1-10. (https:// doi.org/10.1621/nrs.06003)

Zheng S, Huang J, Zhou K, Zhang C, Xiang Q, Tan Z, Wang T \& Fu X 2011 17 $\beta$-Estradiol enhances breast cancer cell motility and invasion via extra-nuclear activation of actin-binding protein ezrin. PLOS ONE 6 e22439. (https://doi.org/10.1371/journal.pone.0022439)

Zhou F, Bouillard B, Pharaboz-Joly MO \& André J 1989 Non-classical antiestrogenic actions of dexamethasone in variant MCF-7 human breast cancer cells in culture. Molecular and Cellular Endocrinology 66 189-197. (https://doi.org/10.1016/0303-7207(89)90031-2)

Received in final form 4 June 2018

Accepted 12 June 2018

Accepted Preprint published online 13 June 2018
๑) 2018 Society for Endocrinology Published by Bioscientifica Ltd. Printed in Great Britain 